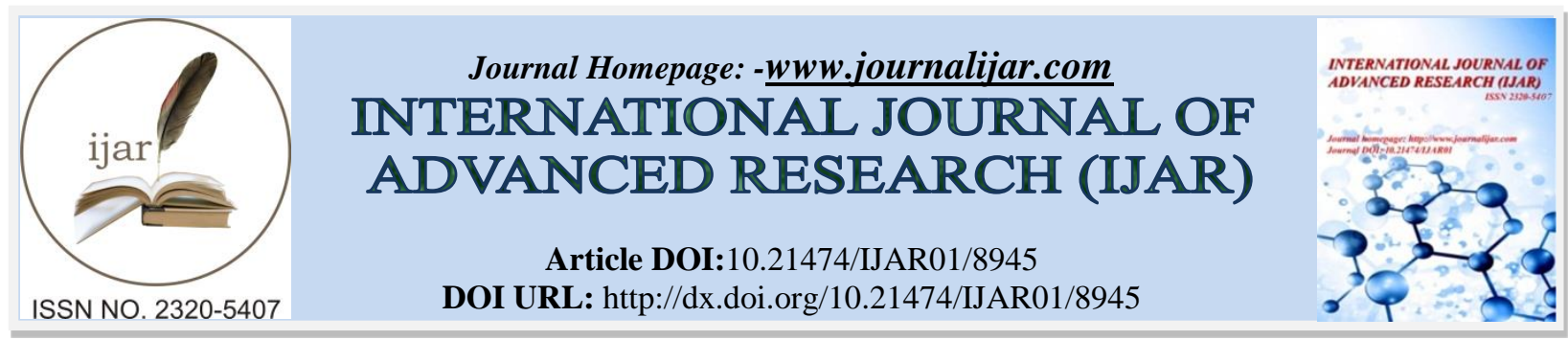

RESEARCH ARTICLE

\title{
MASS LOAD CASCADE ANALYSIS APPROACH FOR HYDROGEN AND WATER UTILITY NETWORK DESIGN.
}

Walaa Mahmoud Shehata.

Faculty of Petroleum and Mining Engineering, Department of Petroleum Refining and Petrochemical Engineering, Suez University, Suez, Egypt.

\section{Manuscript Info}

\section{Manuscript History}

Received: 22 February 2019

Final Accepted: 24 March 2019

Published: April 2019

Key words:-

hydrogen network; water network; reuse/recycle; partitioning regeneration; single-pass regeneration

\section{Abstract}

This paper addresses the mass load cascade analysis (MLCA) for reuse/recycle and regeneration of hydrogen and water networks as an extension to the mass problem table for targeting the minimum water flowrate in reuse/recycle water network. The MLCA technique gives the pinch concentration and accurate identification of minimum fresh hydrogen and water flowrates required for utility network after sourcesink allocation targets. Additionally, selection of hydrogen purification unit was accessed via MLCA. All these targets are determined ahead of detailed design of utility network. Different hydrogen and water network case studies from literature are solved to illustrate the proposed approach.

Copy Right, IJAR, 2019, All rights reserved.

\section{Introduction:-}

As a result of restrictive environmental regulations, the world tends to reduce waste and prevent pollution. Process integration is considered as an effective tool for saving the energy and the mass in industry in recent decades. It is used in heat integration to reduce power consumption and maximize heat recovery [1], [2], [3]. In addition, it is used in mass exchange networks [4], [5], [6], [7], [8], [9], water networks [10], [11], [12], [13], [14] and material recycle [15], [16]. In recent years, process integration is used in hydrogen networks to minimize hydrogen supply in refineries [17], [18], [19], [20], [21]. That helps refineries in minimizing the operating cost of fresh hydrogen supply. There are two approaches in process integration. The first approach is based on the pinch analysis approach [12], [13], [14], [15], [16], [18], [19], [22], [23] and the second is based on the mathematical programming approach [24], [25], [26], [27], [28]. The pinch analysis approach exists in two techniques, graphical targeting technique [12], [15], [16], [18] and numerical targeting technique [13], [14], [19], [22], [23].

This paper presents the numerical mass load cascade analysis (MLCA) technique based on pinch analysis approach to obtain the minimum flowrate of fresh source and minimum waste flowrate in hydrogen and water networks. MLCA is an extension of the mass problem table technique [14] to target water networks.

The mass problem table technique cannot deal with an impure fresh source of reuse/recycle of water networks. In addition, the new fresh source may have a higher impurity concentration than the process sources, especially in the hydrogen network. In the hydrogen network, the source of fresh hydrogen is rarely pure. Also, the mass problem table technique does not deal with the regeneration process when it is included in the overall water network.

Corresponding Author:-Walaa Mahmoud Shehata.

Address:-Faculty of Petroleum and Mining Engineering, Department of Petroleum Refining and

Petrochemical Engineering, Suez University, Suez, Egypt. 
In this work, the mass problem table technique was modified to the MLCA technique to address the previous limitations. MLCA can be used as a general tool to obtain a minimum of both fresh source flowrate and waste disposal flowrate for hydrogen and water networks. In addition, it is used in reuse//recycle for different impurity concentrations of fresh utility and in the regeneration process.

\section{Problem Statement}

For a given process there are

1. Set of process hydrogen and water sources: $\operatorname{SOURCES~}=\left\{i l i=1,2, \ldots, \mathrm{N}_{\text {sources }}\right\}$ Each source with flow rate, $\mathrm{F}_{\mathrm{SR}, \mathrm{i}}$, and a given composition, $\mathrm{C}_{\mathrm{SR}, \mathrm{i}}$

2. Set of process hydrogen/water sinks: $\operatorname{SINKS}=\left\{j \mid j=1,2, \ldots, \mathbf{N}_{\text {sinks }}\right\}$. Each sink with flowrate, $\mathrm{F}_{\mathrm{Sk}, \mathrm{j}}$, and composition $\mathrm{C}_{\mathrm{SK}, \mathrm{j}}$

3. A fresh (external) source with impurity concentration $\mathrm{C}_{\mathrm{F}}$ can be purchased to supplement the use of process sources.

4. Single - pass or partitioning regeneration unit that is used to reduce the targeted species from the sources

The overall objective of this work is solving the problem by MLCA technique to allocate sources to sinks in reuse/recycle integration system, and then it is expanded to the regeneration process to satisfy the demands of the sinks.

\section{Mass Load Cascade Analysis Technique (MLCA)}

The mass load cascade analysis technique includes two steps to be applicable for all impurity concentration types of fresh utility. The first step is the construction of the sources and sinks cumulative loads table. The second step is the construction of the mass load cascade analysis table.

\section{Step 1: Sources and Sinks Cumulative Loads Table}

The first step in conducting MLCA is the construction of the sources and the sinks cumulative loads table (Table 1). As illustrated in Table 1, the source load is obtained from the product of source flowrate (FSR, i) and the difference between the source concentration $\left(\mathrm{C}_{\mathrm{SR}},{ }_{\mathrm{i}}\right)$ and the concentration of fresh hydrogen/water source $\left(\mathrm{C}_{\mathrm{F}}\right)$. By the same way, the sink load is obtained from the product of sink flowrate $\left(\mathrm{F}_{\mathrm{SK}, \mathrm{j}}\right)$ and the difference between the sink concentration $\left(\mathrm{C}_{\mathrm{SK}}, \mathrm{j}\right)$ and the concentration of fresh hydrogen/water source $\left(\mathrm{C}_{\mathrm{F}}\right)$.

Table 1:-Sources and Sinks cumulative loads

\begin{tabular}{|c|c|c|c|c|c|c|c|c|c|}
\hline $\begin{array}{c}\text { Source } \\
\text { streams } \\
\left(\mathrm{SR}_{,}\right)\end{array}$ & $\begin{array}{c}\text { Source } \\
\text { flowrate } \\
\left(\mathrm{F}_{\mathrm{SR}, \mathrm{i}}\right)\end{array}$ & $\begin{array}{l}\text { Source } \\
\text { Conc. } \\
\left(\mathrm{C}_{\mathrm{SR}, \mathrm{i}}\right)\end{array}$ & $\begin{array}{l}\text { Source load } \\
\left(\mathrm{M}_{\mathrm{SR}, \mathrm{i}}\right)\end{array}$ & $\begin{array}{c}\text { Cumulative } \\
\text { load } \\
\text { (Cum } \mathrm{M}_{\mathrm{SR}, \mathrm{i}} \text { ) }\end{array}$ & $\begin{array}{c}\text { Sink } \\
\text { streams } \\
\left(\mathrm{SK}_{, j}\right)\end{array}$ & $\begin{array}{c}\text { Sink } \\
\text { flowrate } \\
\left(F_{S k, j}\right)\end{array}$ & $\begin{array}{c}\text { Sink } \\
\text { Conc. } \\
\left(\mathrm{C}_{\mathrm{SK}, \mathrm{j}}\right)\end{array}$ & $\begin{array}{c}\text { Sink load } \\
\left(\mathrm{M}_{\mathrm{SK}, \mathrm{j}}\right)\end{array}$ & $\begin{array}{c}\text { Cumulative } \\
\text { load } \\
\left(\text { Cum } \mathrm{M}_{\mathrm{SK}, \mathrm{j}}\right)\end{array}$ \\
\hline $\mathrm{SR}, 1$ & $\mathrm{~F}_{\mathrm{SR}, 1}$ & $\mathrm{C}_{\mathrm{SR}, 1}$ & $\mathrm{~F}_{\mathrm{SR}, 1} *\left(\mathrm{C}_{\mathrm{SR}, 1}-\mathrm{C}_{\mathrm{F}}\right)$ & $0+\mathrm{M}_{\mathrm{sR}, 1}$ & $\mathrm{SK}_{, 1}$ & $\mathrm{~F}_{\mathrm{SK}, 1}$ & $\mathrm{C}_{\mathrm{SK}, 1}$ & $\mathrm{FSK}_{\mathrm{SK}, 1} *\left(\mathrm{CSK}_{\mathrm{SK}, 1}-\mathrm{C}_{\mathrm{F}}\right)$ & $0+\mathrm{MSK}_{\mathrm{SK}}$ \\
\hline $\mathrm{SR}_{, 2}$ & $\mathrm{~F}_{\mathrm{SR}, 2}$ & $\mathrm{C}_{\mathrm{SR}, 2}$ & $\mathrm{~F}_{\mathrm{SR}, 2} *\left(\mathrm{C}_{\mathrm{SR}, 2-} \mathrm{C}_{\mathrm{F}}\right)$ & $\begin{array}{c}\text { Cum } \mathrm{M}_{\mathrm{SR}, 1} \\
+\mathrm{M}_{\mathrm{SR}, 2}\end{array}$ & $\mathrm{SK}_{, 2}$ & $\mathrm{~F}_{\mathrm{SK}, 2}$ & $\mathrm{C}_{\mathrm{SK}, 2}$ & $\mathrm{~F}_{\mathrm{SK}, 2} *\left(\mathrm{C}_{\mathrm{SK}, 2-}-\mathrm{C}_{\mathrm{F}}\right)$ & $\begin{array}{c}\text { Cum } \mathrm{M}_{\mathrm{SK}, 1} \\
+\mathrm{M}_{\mathrm{SK}, 2} \\
\end{array}$ \\
\hline $\begin{array}{l}1 \\
1 \\
1\end{array}$ & $\begin{array}{l}1 \\
1\end{array}$ & $\begin{array}{l}1 \\
1 \\
1\end{array}$ & $\begin{array}{l}1 \\
1\end{array}$ & l & $\begin{array}{l}1 \\
1\end{array}$ & 1 & $\begin{array}{l}1 \\
1 \\
1\end{array}$ & $\begin{array}{l}1 \\
1\end{array}$ & $\begin{array}{l}1 \\
1\end{array}$ \\
\hline $\mathrm{SR}, \mathrm{n}$ & $\mathrm{F}_{\mathrm{SR}, \mathrm{n}}$ & $\mathrm{CSR}, \mathrm{n}$ & $\mathrm{F}_{\mathrm{SR}, \mathrm{n}} *\left(\mathrm{C}_{\mathrm{SR}, \mathrm{n}}-\mathrm{C}_{\mathrm{F}}\right)$ & $\begin{array}{l}\text { Cum MsR, n-1 } \\
+M_{S R, n}\end{array}$ & $\mathrm{SK}, \mathrm{m}$ & $\mathrm{F}_{\mathrm{SK}, \mathrm{m}}$ & $\mathrm{CSK}, \mathrm{m}$ & $\begin{array}{c}\mathrm{F}_{\mathrm{SK}, \mathrm{m}^{*}}{ }^{*}\left(\mathrm{C}_{\mathrm{SK}, \mathrm{m}^{-}}\right. \\
\left.\mathrm{C}_{\mathrm{F}}\right)\end{array}$ & $\begin{array}{c}\text { Cum } M_{s K, m-1} \\
+M_{S K, m}\end{array}$ \\
\hline
\end{tabular}

The second step in adapting the MLCA is the construction of mass load cascade table for reuse/recycle integration system to determine the minimum fresh and discharge utility flowrates target for the hydrogen and water networks and the location of the pinch point. Step 2 can be extended to be used for regeneration system with some different constraint.

\section{Step 2: Mass Load Cascade Analysis Table for Reuse/recycle Hydrogen and Water Utility Networks}

As illustrated in Table 2, the mass load cascade table composes of 12 columns. Column 1 presents the number of cumulative loads intervals. Column $2\left(\mathrm{M}_{\mathrm{k}}\right)$ is the ascending order of the cumulative loads of sources and sinks described in Table 1. The cascade order in this column starts with zero cumulative load. Column 3 represents the net cumulative loads $\left(\Delta M_{K}\right)$ within the intervals. In columns 4 and 6 , sources and sinks cumulative loads are arranged in an ascending order at their respective cumulative load interval. Where each source/sink starts at its cumulative load and ends at the cumulative load of the next source/sink. Columns 5 and 7 represent the concentration of the sources and the sinks corresponding to the sources and the sinks types in columns 4 and 6 , respectively. The interval source 
flowrate $\left(\Delta \mathrm{M}_{\mathrm{SR}, \mathrm{K}}\right)$ in column 8 is obtained by dividing the net interval load $\left(\Delta \mathrm{M}_{\mathrm{K}}\right)$ at level $\mathrm{k}$ by the difference between the source concentration at that level and the fresh feed concentration $\left(\mathrm{C}_{\mathrm{F}}\right)$. The same procedure applied in column 8 is repeated in column 9 for interval sink flowrate $\left(\Delta \mathrm{M}_{\mathrm{SK}, \mathrm{K}}\right)$. The net flowrate between the source and the sink $\left(\Delta \mathrm{S}_{\mathrm{k}}\right)$ in column 10 is calculated as the difference between the source flowrate $\left(\Delta \mathrm{M}_{\mathrm{SR}, \mathrm{k}}\right.$, column 8$)$ and the sink flowrate $\left(\Delta \mathrm{M}_{\mathrm{SK}, \mathrm{k}}\right.$, column 9$)$ at each net interval cumulative load. The negative sign in this column indicates that there is a deficit but the positive sign indicates that there is a surplus.

The two last columns in MLCA table indicate the minimum fresh and discharge utility flowrate and the pinch point concentration. The net flowrate between sources and sinks $\left(\Delta S_{\mathrm{k}}\right.$, column 10) is cascaded down from top to bottom in columns $11\left(\right.$ Cum $\left.\Delta \mathrm{S}_{\mathrm{k}}\right)$ and $12\left(\mathrm{Cum} \Delta \mathrm{Q}_{\mathrm{k}}\right)$. The start of the cascade analysis in column 11 begins with zero fresh hydrogen/water flowrate to facilitate the search for the minimum fresh utility flowrate. The absolute value of the largest negative value obtained in column 11 represents the minimum fresh utility flowrate target. The procedure applied in column 11 is repeated in column 12 but with starting the cascade analysis with the absolute value of the largest negative value obtained in column 11. This value cascaded down the net flowrate $\left(\Delta \mathrm{S}_{\mathrm{k}}\right.$, column 10) yields the minimum discharge utility flowrate target (last value in column 12). The pinch point location and concentration of the hydrogen/water network exists at the zero value of the cascade net flowrate in column 12.

Table 2:-General mass load cascade analysis

\begin{tabular}{|c|c|c|c|c|c|c|c|c|c|c|c|}
\hline $\begin{array}{c}\text { Interval } \\
\mathbf{k}\end{array}$ & $\begin{array}{c}\text { Cumulative } \\
\text { load }\left(M_{k}\right)\end{array}$ & $\begin{array}{c}\text { Net interval } \\
\text { cumulative } \\
\text { Loads } \\
\Delta \mathbf{M}_{\mathrm{k}}\end{array}$ & $\begin{array}{l}\text { Process } \\
\text { sources } \\
\text { SR }_{k}\end{array}$ & $\begin{array}{l}\text { Source } \\
\text { conc. } \\
\text { C }_{\mathrm{SR}, \mathrm{k}}\end{array}$ & $\begin{array}{l}\text { Process } \\
\text { Sinks } \\
\text { SK }_{\mathrm{k}}\end{array}$ & $\begin{array}{l}\text { Sink } \\
\text { conc. } \\
\mathrm{C}_{\mathrm{SK}, \mathrm{k}}\end{array}$ & $\begin{array}{c}\text { Interval Source } \\
\text { flowrate } \\
\Delta \mathrm{M}_{\mathrm{SR}, \mathrm{k}}\end{array}$ & $\begin{array}{c}\text { Interval } \\
\text { Sink } \\
\text { flowrate } \\
\Delta \mathbf{M}_{\mathrm{SK}, \mathrm{k}}\end{array}$ & $\begin{array}{c}\text { Net } \\
\text { flowrate } \\
\Delta \mathbf{S}_{\mathrm{k}}\end{array}$ & $\begin{array}{c}\text { Cascade net } \\
\text { flowrate } \\
\text { Cum } \Delta S_{k} \\
0\end{array}$ & $\begin{array}{c}\text { Cascade net } \\
\text { flowrate } \\
\text { Cum } \Delta Q_{\mathrm{k}} \\
\\
\text { Fresh } \\
\text { source } \\
\text { flowrate }= \\
\text { min cum } \\
\Delta S_{\mathrm{k}}\end{array}$ \\
\hline \multirow[t]{2}{*}{$\mathbf{k}$} & $\mathbf{M}_{\mathrm{k}}=\mathbf{0}$ & & & & & & & & & & \\
\hline & & $\mathbf{M}_{\mathrm{k+1}-\mathbf{0}}$ & $\mathbf{S R}_{\mathbf{1}}$ & $\mathrm{C}_{\mathrm{SR}, 1}$ & $\mathbf{S K}_{1}$ & $\mathrm{C}_{\mathrm{SK}, 1}$ & $\Delta \mathbf{M}_{\mathrm{k}} /\left(\mathbf{C}_{\left.\mathrm{SR}, 1-\mathrm{C}_{\mathrm{F}}\right)}\right.$ & $\Delta \mathbf{M}_{\mathrm{k}} /\left(\mathbf{C}_{\mathrm{SK}, 1}-\mathrm{C}_{\mathrm{F}}\right)$ & $\Delta \mathbf{M}_{\mathrm{SR}, \mathrm{k}}-\Delta \mathrm{M}_{\mathrm{SK}, \mathrm{k}}$ & $0+\Delta S_{k}$ & $\begin{array}{l}\min \operatorname{cum} \\
\Delta \mathrm{S}_{\mathrm{k}}+\Delta \mathrm{S}_{\mathrm{k}}\end{array}$ \\
\hline \multirow[t]{2}{*}{$\mathrm{K}+1$} & $\mathbf{M}_{\mathrm{k}+1}$ & & $\mathbf{S R}_{\mathbf{1}}$ & $\mathrm{C}_{\mathrm{SR}, 1}$ & $\mathbf{S K}_{1}$ & $\mathrm{C}_{\mathrm{SK}, 1}$ & & & & & \\
\hline & & $\mathbf{M}_{\mathbf{k}+2-} \mathbf{M}_{\mathrm{k}+1}$ & $\mathbf{S R}_{2}$ & $\mathrm{C}_{\mathrm{SR}, 2}$ & $\mathbf{S K}_{1}$ & $\mathrm{C}_{\mathrm{SK}, 1}$ & $\Delta \mathbf{M}_{\mathrm{k}+1} /\left(\mathbf{C}_{\mathrm{SR}, 2}-\mathrm{C}_{\mathrm{F}}\right)$ & $\Delta \mathbf{M}_{\mathbf{k}+1} /\left(\mathrm{C}_{\mathbf{S K}, \mathbf{1}}-\mathrm{C}_{\mathbf{F}}\right)$ & $\Delta \mathbf{M}_{\mathrm{SR}, \mathrm{k}+1^{-}} \Delta \mathbf{M}_{\mathrm{SK}, \mathrm{k}+1}$ & $\begin{array}{c}\operatorname{Cum} \Delta \mathbf{S}_{k}+ \\
\Delta \mathbf{S}_{k+1} \\
\end{array}$ & $\begin{array}{c}\operatorname{Cum} \Delta Q_{k}+ \\
\Delta S_{k+1} \\
\end{array}$ \\
\hline \multirow[t]{2}{*}{$\mathrm{K}+2$} & $\mathbf{M}_{\mathbf{k}+2}$ & & $\mathbf{S R}_{2}$ & $\mathrm{C}_{\mathrm{SR}, 2}$ & $\mathbf{S K}_{1}$ & $\mathrm{C}_{\mathrm{SK}, 1}$ & & & & & \\
\hline & & $\mathbf{M}_{\mathbf{k}+3-} \mathbf{M}_{\mathrm{k}+2}$ & $\mathbf{S R}_{3}$ & $\mathrm{C}_{\mathrm{SR}, 3}$ & $\mathbf{S K}_{2}$ & $\mathrm{C}_{\mathrm{SK}, 2}$ & $\Delta \mathbf{M}_{\mathrm{k}+2} /\left(\mathrm{C}_{\left.\mathrm{SR}, 3-\mathrm{C}_{\mathrm{F}}\right)}\right.$ & $\Delta \mathbf{M}_{\mathrm{k}+2} /\left(\mathrm{C}_{\left.\mathrm{SK}, 2-\mathrm{C}_{\mathrm{F}}\right)}\right.$ & $\Delta M_{\mathrm{SR}, \mathrm{k}+2-} \Delta \mathrm{M}_{\mathrm{SK}, \mathrm{k}+2}$ & $\begin{array}{c}\underset{\Delta S_{k+2}}{\operatorname{Cum}} \Delta S_{k+1}+ \\
\end{array}$ & $\begin{array}{c}\text { Cum } \\
\Delta \mathbf{Q}_{\mathrm{k}+1+} \\
\Delta \mathbf{S}_{\mathrm{k}+2} \\
\end{array}$ \\
\hline \multirow[t]{2}{*}{$\mathbf{K}+3$} & $\mathbf{M}_{k+3}$ & & $\mathbf{S R}_{3}$ & $\mathrm{C}_{\mathrm{SR}, 3}$ & $\mathbf{S K}_{2}$ & $\mathrm{C}_{\mathrm{SK}, 2}$ & & & & & \\
\hline & & $\mathbf{M}_{k+4^{-}} \mathbf{M}_{\mathrm{k}+3}$ & $\mathbf{S R}_{4}$ & $\mathrm{C}_{\mathrm{SR}, 4}$ & $\mathrm{SK}_{3}$ & $\mathrm{C}_{\mathrm{SK}, 3}$ & $\Delta \mathbf{M}_{\mathrm{k}+3} /\left(\mathrm{C}_{\mathrm{SR}, 4}-\mathrm{C}_{\mathrm{F}}\right)$ & $\begin{array}{c}\Delta \mathbf{M}_{\mathrm{k}+3} /\left(\mathbf{C}_{\mathrm{SK}, 3^{-}}\right. \\
\left.\mathbf{C}_{\mathbf{F}}\right) \\
\end{array}$ & $\Delta M_{\mathrm{SR}, \mathbf{k}+3^{-}} \Delta \mathbf{M}_{\mathrm{SK}, \mathbf{k}+3}$ & $\begin{array}{c}\operatorname{Cum} \Delta S_{k+2+} \\
\Delta S_{k+3} \\
\end{array}$ & $\begin{array}{c}\text { Cum } \\
\Delta \mathbf{Q}_{\mathbf{k}+2+} \\
\Delta \mathbf{S}_{\mathrm{k}+3} \\
\end{array}$ \\
\hline \multirow[t]{2}{*}{$\mathrm{K}+4$} & $\mathbf{M}_{k+4}$ & & $\mathbf{S R}_{4}$ & $\mathrm{C}_{\mathrm{SR}, 4}$ & $\mathbf{S K}_{3}$ & $\mathrm{C}_{\mathrm{SK}, 3}$ & & & & & \\
\hline & & $\mathbf{M}_{\mathbf{k}+5^{-}} \mathbf{M}_{\mathbf{k}+4}$ & $\mathbf{S R}_{5}$ & $\mathrm{C}_{\mathrm{SR}, 5}$ & $\mathrm{SK}_{4}$ & $\mathrm{C}_{\mathrm{SK}, 4}$ & $\Delta \mathbf{M}_{\mathrm{k}+4} /\left(\mathbf{C}_{\mathrm{SR}, 5}-\mathbf{C}_{\mathrm{F}}\right)$ & $\begin{array}{c}\Delta \mathbf{M}_{\mathrm{k}+4} / \mathbf{C}_{S K, 4-} \\
\left.\mathbf{C}_{\mathrm{F}}\right)\end{array}$ & $\Delta \mathbf{M}_{\mathrm{SR}, \mathbf{k}+4^{-}} \Delta \mathbf{M}_{\mathrm{SK}, \mathbf{k}+4}$ & $\begin{array}{c}\operatorname{Cum} \Delta \mathbf{S}_{k+3+}+ \\
\Delta \mathbf{S}_{k+4} \\
\end{array}$ & $\begin{array}{c}\text { Cum } \\
\Delta \mathbf{Q}_{\mathrm{k}+3+} \\
\Delta \mathbf{S}_{\mathrm{k}+4} \\
\end{array}$ \\
\hline $\mathrm{K}+5$ & $\mathbf{M}_{k+4}$ & & $\mathbf{S R}_{5}$ & $\mathrm{C}_{\mathrm{SR}, 5}$ & $\mathrm{SK}_{4}$ & $\mathrm{C}_{\mathrm{SK}, 4}$ & & & & & \\
\hline $\begin{array}{l}1 \\
1 \\
1\end{array}$ & $\begin{array}{l}1 \\
1 \\
1\end{array}$ & $\begin{array}{l}1 \\
1 \\
1\end{array}$ & $\begin{array}{l}1 \\
1\end{array}$ & $\begin{array}{l}1 \\
1\end{array}$ & $\begin{array}{l}1 \\
1 \\
1\end{array}$ & $\begin{array}{l}1 \\
1\end{array}$ & $\begin{array}{l}1 \\
1 \\
1\end{array}$ & $\begin{array}{l}1 \\
1 \\
1\end{array}$ & $\begin{array}{l}1 \\
1\end{array}$ & 1 & $\begin{array}{l}1 \\
1 \\
1\end{array}$ \\
\hline \multirow[t]{2}{*}{ n-1 } & $M_{n-1}$ & & $\mathbf{S R}_{\mathrm{n}-1}$ & $\mathrm{C}_{\mathrm{SR}, \mathrm{n}-1}$ & $\mathbf{S K}_{\mathrm{n}-1}$ & $\mathrm{C}_{\mathrm{SK}, \mathrm{n}-1}$ & & & & & \\
\hline & & $\mathbf{M}_{\mathbf{n}}-\mathbf{M}_{\mathrm{n}-1}$ & $\mathbf{S R}_{\mathrm{n}-1}$ & $\mathrm{C}_{\mathrm{SR}, \mathrm{n}-1}$ & $\mathrm{SK}_{\mathrm{n}-1}$ & $\mathrm{C}_{\mathrm{SK}, \mathrm{n} \cdot \mathrm{1}}$ & $\begin{array}{c}\Delta \mathbf{M}_{\mathrm{n}-1} /\left(\mathbf{C}_{\mathrm{SR}, \mathrm{n}-1^{-}}\right. \\
\left.\mathbf{C}_{\mathrm{F}}\right)\end{array}$ & $\begin{array}{c}\Delta \mathbf{M}_{\mathrm{n}-1} /\left(\mathbf{C}_{\mathrm{SK}, \mathrm{n}-1^{-}}\right. \\
\left.\mathbf{C}_{\mathrm{F}}\right)\end{array}$ & $\Delta M_{S R, n-1^{-}} \Delta M_{S K, n-1}$ & $\begin{array}{c}\operatorname{Cum} \Delta S_{n-2+}+ \\
\Delta S_{n-1}\end{array}$ & $\begin{array}{c}\operatorname{Cum} \Delta Q_{n-} \\
2^{+} \Delta S_{n-1}\end{array}$ \\
\hline $\mathbf{n}$ & $\mathbf{M}_{\mathrm{n}}$ & & $\mathbf{S R}_{\mathrm{n}}$ & $\mathrm{C}_{\mathrm{SR}, \mathrm{n}}$ & $\mathbf{S K}_{\mathrm{n}}$ & $\mathrm{C}_{\mathrm{SK}, \mathrm{n}}$ & & & & & \\
\hline
\end{tabular}

Network design

In this work the network design technique based on pinch point calculations presented by El Halwagi [6], Prakash and Shenoy [23], Aly et al. [14] and Foo and Manan [29] is applied. In this technique, network design depends on the concentration at the pinch point. Where the design of the network is divided into two regions. The first region is the area above pinch concentration while the second region is the area below pinch concentration. In the region above the pinch, fresh water is used while below the pinch, wastewater is discharged. Also, cumulative load surplus is in load balance with load deficit above the pinch. But in the region below the pinch, there is always excess impurity load. The fresh utility source and the other sources above the pinch must not supplied to the sinks below the pinch. The source located at the pinch is divided by the pinch into two parts. The first part belongs the region above the pinch and the second part belongs the region below the pinch. If there is part of any source is not supplied to any sink, it is discharged to the waste. For each sink $j$, its flowrate is the summation of all sources $\left(\sum_{i} F_{i, j}\right)$ supplied to it at its cumulative interval load. If the sink demand is not completed by the sources located in the same 
cumulative interval load, it completes its demand from the sources residual from the above cumulative intervals and the fresh source. The overall flowrate and impurity concentration balance for sink $j$ are applied as described in Equations 1 and 2, respectively. For each source $i$, the overall flowrate balance is applied as illustrated in Equation 3.

$$
\begin{gathered}
F_{S K, j}=\sum_{i} F_{i, j}+\text { fresh }_{j} \\
F_{S K, j} C_{S K, j}=\sum_{i} F_{i, j} C_{S R, i}+\text { fresh }_{j} C_{F} \\
F_{S R, i}=\sum_{i} F_{i, j}
\end{gathered}
$$

Where $F_{i, j}$ is the flowrate from source $\mathrm{i}$ to $\operatorname{sink} j$. fresh $h_{j}$ is the hydrogen flowrate from fresh hydrogen source to sink $j$.

\section{Case study 1: Hydrogen network (fresh hydrogen source has impurity concentration lower than all sources)}

This case study of the hydrogen utility network was presented in this work to apply the MLCA to the gas utility networks. Table 3 presents the hydrogen network composed of 6 hydrogen sources and 4 hydrogen sinks [18]. The fresh hydrogen source is impure and has impurity concentration lower than the impurity concentration of all sources.

\begin{tabular}{|c|c|c|c|c|c|}
\hline Sources & $\begin{array}{c}\text { Flowrate } \\
(\mathrm{mol} / \mathrm{s})\end{array}$ & $\begin{array}{c}\begin{array}{c}\text { Concentration } \\
(\mathrm{mol} \%)\end{array} \\
\end{array}$ & Sinks & $\begin{array}{c}\begin{array}{c}\text { Flowrate } \\
(\mathrm{mol} / \mathrm{s})\end{array} \\
\end{array}$ & $\begin{array}{c}\begin{array}{c}\text { Concentration } \\
(\mathrm{mol} \%)\end{array} \\
\end{array}$ \\
\hline HCU (Hydrocraking unit) & 1801.9 & 25 & $\mathrm{HCU}$ & 2495 & 19.39 \\
\hline NHT (Naphtha hydrotreating) & 138.6 & 25 & NHT & 180.2 & 21.15 \\
\hline CNHT (Cracked naphtha hydrotreating) & 457.4 & 30 & CNHT & 720.7 & 24.86 \\
\hline DHT (Diesel hydrotreating) & 346.5 & 27 & DHT & 554.4 & 22.43 \\
\hline SRU (Steam reforming unit) & 623.8 & 7 & & & \\
\hline CRU (Catalytic reforming unit) & 415.8 & 20 & & & \\
\hline Fresh Hydrogen utility & To be determined & 5 & & & \\
\hline
\end{tabular}
It is supplied to this network at impurity concentration of $5 \%$ and flowrate of $277.2 \mathrm{~mol} / \mathrm{s}$.

Table 3:-Sources and sinks data for case study 1

The first step to get the minimum fresh hydrogen and hydrogen discharge targets for this case study is to construct the sources and sinks cumulative loads table as presented in Table 4. The cumulative loads of sources and sinks

\begin{tabular}{|c|c|c|c|c|c|c|c|c|c|}
\hline Sources & $\begin{array}{c}\text { Flowrate } \\
(\mathrm{mol} / \mathrm{s})\end{array}$ & $\begin{array}{l}\text { Conc. } \\
(\mathrm{mol} / \mathrm{s})\end{array}$ & $\begin{array}{c}\text { Load } \\
(\mathrm{mol} / \mathrm{s})\end{array}$ & Cum loads & Sinks & $\begin{array}{c}\text { Flowrate } \\
(\mathrm{mol} / \mathrm{s})\end{array}$ & $\begin{array}{l}\text { Conc. } \\
(\mathrm{mol} / \mathrm{s})\end{array}$ & $\begin{array}{c}\text { Load } \\
(\mathrm{mol} / \mathrm{s})\end{array}$ & $\begin{array}{l}\text { Cum } \\
\text { loads }\end{array}$ \\
\hline $\mathrm{SR}_{1}(\mathrm{SRU})$ & 623.8 & 7 & 12.476 & 12.476 & $\mathrm{SK}_{1}(\mathrm{HCU})$ & 2495 & 19.39 & 359.0305 & 359.0305 \\
\hline $\mathrm{SR}_{2}(\mathrm{CRU})$ & 415.8 & 20 & 62.37 & 74.846 & $\mathrm{SK}_{2}(\mathrm{NHT})$ & 180.2 & 21.15 & 29.1023 & 388.1328 \\
\hline $\mathrm{SR}_{3}(\mathrm{HCU})$ & 1801.9 & 25 & 360.38 & 435.226 & $\mathrm{SK}_{3}(\mathrm{DHT})$ & 554.4 & 22.43 & 96.63192 & 484.7647 \\
\hline $\mathrm{SR}_{4}(\mathrm{NHT})$ & 138.6 & 25 & 27.72 & 462.946 & $\mathrm{SK}_{4}(\mathrm{CNHT})$ & 720.7 & 24.86 & 143.13102 & 627.8957 \\
\hline $\mathrm{SR}_{5}(\mathrm{DHT})$ & 346.5 & 27 & 76.23 & 539.176 & & & & & \\
\hline $\mathrm{SR}_{6}(\mathrm{CNHT})$ & 457.4 & 30 & 114.35 & 653.526 & & & & & \\
\hline
\end{tabular}
obtained from Table 4 are arranged in ascending order in Table 5 (step 2 in construction of MLCA).

Table 4:- Sources and sinks cumulative loads for reuse/recycle for case study 1

As illustrated in Table 5, the absolute value of the largest negative value of the cascade net flowrate in column 11 is $268.821 \mathrm{~mol} / \mathrm{s}$. This value is equivalent to the minimum fresh hydrogen target for the studied hydrogen network. Note that the negative value in the cascade net flowrate in column 11 indicates insufficient fresh hydrogen in the cumulative loads interval and the positive value indicates excessive fresh hydrogen. The minimum fresh hydrogen $268.821 \mathrm{~mole} / \mathrm{s}$ is cascaded down the net flowrate column ( $\Delta \mathrm{Sk}$, column 10) in Table 5, to yield the minimum discharge hydrogen flowrate of $102.521 \mathrm{~mol} / \mathrm{s}$ (column 12, row 21). As illustrated in column 12. The pinch concentration for the hydrogen network at which the cascade net flowrate Cum $\Delta \mathrm{Q}_{\mathrm{k}}$ (column 12) is zero exists at 30 mol\% (concentration of source 6). These results agree with the results obtained by previous works [19], [18], [29], [30].

In designing the hydrogen network above the pinch concentration, the sink located at cumulative loads interval $k$ takes its demand from sources located at the same cumulative loads interval and completes its demand from any sources residual from the above cumulative loads interval and the fresh hydrogen source. As illustrated in Table 5, 
sink 1 locates in cumulative loads intervals 2, 3 and 4. It takes its demand from sources 1, 2 and 3 and completes its demand from fresh hydrogen source. These sources are located at the same cumulative load intervals. It takes 623.8 $\mathrm{mol} / \mathrm{s}$ from source 1, $415.8 \mathrm{~mol} / \mathrm{s}$ from source 2, $1420.9225 \mathrm{~mol} / \mathrm{s}$ from source 3 and $34.4775 \mathrm{~mol} / \mathrm{s}$ from the fresh hydrogen source. Sink 2 locates in cumulative loads interval 5 and takes $145.5115 \mathrm{~mol} / \mathrm{s}$ from source 3 and 34.6885 $\mathrm{mol} / \mathrm{s}$ from the fresh source. Sink 3 locates in cumulative loads intervals 6,7 and 8 . It takes $235.366 \mathrm{~mol} / \mathrm{s}$ from source $3,138.6 \mathrm{~mol} / \mathrm{s}$ from source $4,99.176 \mathrm{~mol} / \mathrm{s}$ from source 5 and $81.158 \mathrm{~mol} / \mathrm{s}$ from the fresh source. Sink 4 locates in cumulative loads intervals 9 and 10. It takes $247.324 \mathrm{~mol} / \mathrm{s}$ from source $5,354.8789 \mathrm{~mol} / \mathrm{s}$ from source 6 and $118.497 \mathrm{~mol} / \mathrm{s}$ from the fresh source. In the region below the pinch concentration, there is $102.521 \mathrm{~mol} / \mathrm{s}$ from source 6 and there are not any sinks. Thus this amount of source 6 is discharged. The hydrogen network design for case study 1 is shown in Figure 1.

Table 5:-Mass load cascade analysis for reuse/recycle of case study 1

\begin{tabular}{|c|c|c|c|c|c|c|c|c|c|c|c|}
\hline $\begin{array}{c}\text { Interval } \\
\mathrm{k}\end{array}$ & $\begin{array}{c}\text { Cumulative } \\
\text { load } \\
\left(\mathrm{M}_{\mathrm{k}}\right) \\
(\mathrm{mol} / \mathrm{s})\end{array}$ & $\begin{array}{c}\text { Net } \\
\text { interval } \\
\text { Load } \\
\Delta \mathrm{M}_{\mathrm{k}} \\
(\mathrm{mol} / \mathrm{s})\end{array}$ & $\begin{array}{c}\text { Process } \\
\text { sources } \\
\mathrm{SR}_{\mathrm{k}}\end{array}$ & $\begin{array}{c}\text { Source } \\
\text { conc. } \\
\text { CSR,k }\end{array}$ & $\begin{array}{c}\text { Process } \\
\text { Sinks } \\
\text { SKk }_{k}\end{array}$ & $\begin{array}{l}\text { Sink } \\
\text { conc. } \\
\text { CSK, } k\end{array}$ & $\begin{array}{c}\text { Interval } \\
\text { Source } \\
\text { flowrate } \\
\Delta \mathrm{MsR}, \mathrm{k} \\
(\mathrm{mol} / \mathrm{s})\end{array}$ & $\begin{array}{c}\text { Interval } \\
\text { Sink } \\
\text { flowrate } \\
\Delta \mathrm{Msk}, \mathrm{k} \\
(\mathrm{mol} / \mathrm{s})\end{array}$ & $\begin{array}{c}\text { Net } \\
\text { flowrate } \\
\Delta \mathrm{S}_{\mathrm{k}} \\
(\mathrm{mol} / \mathrm{s})\end{array}$ & $\begin{array}{c}\text { Cascade } \\
\text { net } \\
\text { flowrate } \\
\text { Cum } \Delta \mathrm{S}_{\mathrm{k}} \\
0 \\
0\end{array}$ & $\begin{array}{c}\text { Cascade } \\
\text { net } \\
\text { flowrate } \\
\text { Cum } \Delta \mathrm{Q}_{\mathrm{k}} \\
268.82104\end{array}$ \\
\hline \multirow[t]{2}{*}{1} & 0 & & & & & & & & & & \\
\hline & & 12.476 & source 1 & 7 & sink 1 & 19.39 & 623.8 & 86.6991 & 537.1009 & 537.1009 & 805.9219 \\
\hline \multirow[t]{2}{*}{2} & 12.476 & & source 1 & 7 & sink 1 & 19.39 & & & & & \\
\hline & & 62.37 & source 2 & 20 & sink 1 & 19.39 & 415.8 & 433.426 & -17.626 & 519.4749 & 788.296 \\
\hline \multirow[t]{2}{*}{3} & 74.846 & & source 2 & 20 & sink 1 & 19.39 & & & & & \\
\hline & & 284.185 & source 3 & 25 & sink 1 & 19.39 & 1420.923 & 1974.875 & -553.952 & -34.4775 & 234.3435 \\
\hline \multirow[t]{2}{*}{4} & 359.0305 & & source 3 & 25 & sink 1 & 19.39 & & & & & \\
\hline & & 29.1023 & source 3 & 25 & sink 2 & 21.15 & 145.5115 & 180.2 & -34.6885 & $\begin{array}{l}-69.166 \\
\end{array}$ & 199.655 \\
\hline \multirow[t]{2}{*}{5} & 388.1328 & & source 3 & 25 & sink 2 & 21.15 & & & & & \\
\hline & & 47.0932 & source 3 & 25 & sink 3 & 22.43 & 235.466 & 270.1847 & -34.7187 & -103.885 & 164.9363 \\
\hline \multirow[t]{2}{*}{6} & 435.226 & & source 3 & 25 & sink 3 & 22.43 & & & & & \\
\hline & & 27.72 & source 4 & 25 & sink 3 & 22.43 & 138.6 & 159.0361 & -20.4361 & -124.321 & 144.5002 \\
\hline \multirow[t]{2}{*}{7} & 462.946 & & source 4 & 25 & sink 3 & 22.43 & & & & & \\
\hline & & 21.8187 & source 5 & 27 & sink 3 & 22.43 & 99.176 & 125.1791 & -26.0031 & $\begin{array}{l}-150.324 \\
\end{array}$ & 118.497 \\
\hline \multirow[t]{2}{*}{8} & 484.7647 & & source 5 & 27 & sink 3 & 22.43 & & & & & \\
\hline & & 54.4113 & source 5 & 27 & sink 4 & 24.86 & 247.324 & 273.9742 & -26.6502 & -176.974 & 91.84682 \\
\hline \multirow[t]{2}{*}{9} & 539.176 & & source 5 & 27 & sink 4 & 24.86 & & & & & \\
\hline & & 88.7197 & source 6 & 30 & $\operatorname{sink} 4$ & 24.86 & 354.879 & 446.7258 & -91.8468 & -268.821 & $\begin{array}{l}-1.4 \mathrm{E}-14 \\
\text { (Pinch point) }\end{array}$ \\
\hline \multirow[t]{2}{*}{10} & 627.8957 & & source 6 & 30 & sink 4 & 24.86 & & & & & \\
\hline & & 25.6303 & source 6 & 30 & & & 102.521 & & 102.521 & -166.3 & 102.521 \\
\hline 11 & 653.526 & & source 6 & 30 & & & & & & & \\
\hline
\end{tabular}

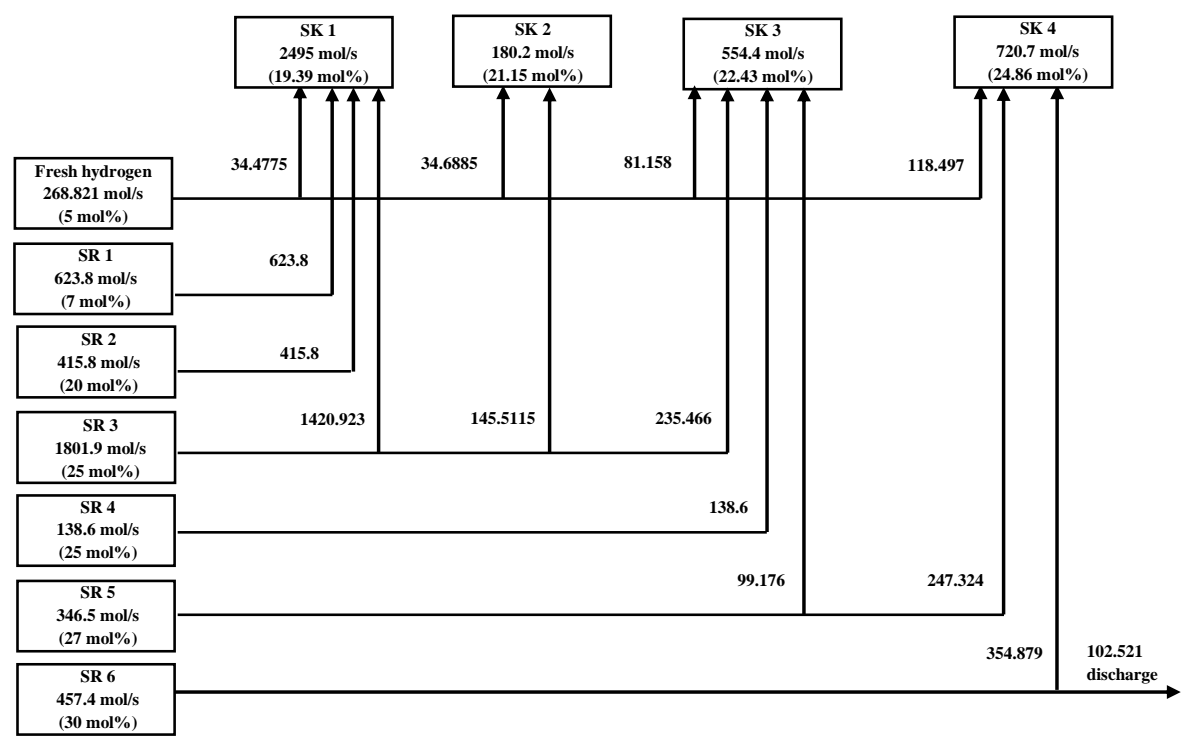

Figure 1:- Hydrogen network design for case study 1 
Case study 2: water network (Fresh water source has impurity concentration higher than some water sources)

This case study is taken from the water minimization in a pulp and paper mill presented by Parthasarathy and Krishnagopalan [31]. It involves 4 water sources and five water sinks with flowrates and concentrations as illustrated in Table 6. The available fresh water source has impurity concentration (4.2 ppm) higher than the water source W13 $(0 \mathrm{ppm})$. In this case study, MLCA will be applied if one or more sources are more pure than the fresh source. Where source 1 is cleaner than the fresh water source.

Table 6:-Sources and Sinks data for case study 2

\begin{tabular}{|c|c|c|c|c|c|}
\hline Sinks & Flowrate, (ton/day) & Concentration, $(\mathrm{ppm})$ & Sources & Flowrate, (ton/day) & Concentration, $(\mathrm{ppm})$ \\
\hline W7 & 7000 & 110 & W13 & 7971 & 0 \\
\hline W18 & 4200 & 5.5 & W8b & 945 & 275 \\
\hline W27 & 2000 & 38.5 & W38 & 14520 & 235 \\
\hline W37 & 12000 & 38.5 & W42 & 13750 & 504 \\
\hline W41 & 11200 & 13.2 & Fresh water source & & 4.2 \\
\hline
\end{tabular}

The sources and sinks cumulative loads table is presented in Table 7. As illustrated in Table 7, the first cumulative loads value in column 10 (first row) is negative value. This result came because the fresh source has higher impurity concentration than the first source W13. The cumulative loads of sources and sinks obtained are arranged ascending order in Table 8 (step 2 in construction of MLCA).

Table 7:-Sources and sinks cumulative loads for case study 2

\begin{tabular}{|c|c|c|c|c|c|c|c|c|c|}
\hline $\begin{array}{l}\text { Sinks } \\
\left(\mathrm{SK}_{, \mathrm{j}}\right) \\
\end{array}$ & $\begin{array}{l}\text { Flowrate } \\
\text { (ton/day) }\end{array}$ & $\begin{array}{c}\text { Concentration } \\
(\mathrm{ppm})\end{array}$ & $\begin{array}{c}\text { Load } \\
(\mathrm{kg} / \text { day })\end{array}$ & $\begin{array}{c}\text { Cum load } \\
\text { (kg/day) }\end{array}$ & $\begin{array}{c}\text { Sourcs } \\
\left(\mathrm{SR}_{\mathrm{j}}\right)\end{array}$ & $\begin{array}{l}\text { Flowrate } \\
\text { (ton/day) }\end{array}$ & $\begin{array}{c}\text { Concentration } \\
(\mathrm{ppm})\end{array}$ & $\begin{array}{c}\text { Load } \\
\text { (kg/day) }\end{array}$ & $\begin{array}{c}\text { Cum load } \\
\text { (kg/day) }\end{array}$ \\
\hline W18 & 4200 & 5.5 & 5.46 & 5.46 & W13 & 7971 & 0 & -33.4782 & -33.4782 \\
\hline W37 & 12000 & 10.12 & 71.04 & 76.5 & W38 & 14520 & 235 & 3351.216 & 3317.738 \\
\hline W41 & 11200 & 13.2 & 100.8 & 177.3 & W8b & 945 & 275 & 255.906 & 3573.644 \\
\hline W27 & 2000 & 38.5 & 68.6 & 245.9 & W42 & 13750 & 504 & 6872.25 & 10445.89 \\
\hline W7 & 7000 & 110 & 740.6 & 986.5 & & & & & \\
\hline
\end{tabular}

As illustrated in Table 8, the minimum fresh water flowrate target is 24009.68 ton/day (column 11, row 13) and the discharge flowrate is 24795.68 ton /day (column 12, row 19). The pinch is located at concentration 235 ppm (concentration of source 2). These results are similar to those obtained by Foo [32]. Note that, in this network, the fresh water source has impurity concentration $(4.2 \mathrm{ppm})$ higher than one of the sources (W13). In designing the network above the pinch concentration, each sink will take its demand from the sources located at its cumulative load interval and sources residual from the above cumulative load intervals. If the sources and the sources residual are less than the sink demand, the sink will complete its demand from the fresh water source. After consuming of the fresh water target, sinks completes their demand from source 1 which is more pure $(0 \mathrm{ppm})$ than the fresh water source.

As described in Table 8, sink 1 locates in cumulative load intervals 2 and 3. It takes 23.657 ton/day from source 2 and 4176.343 ton/day from fresh water source. Note that, if sink 1 took 168.7097 ton/day (column 8, row 5) from source 2 and the remainder 4031.9 ton/day from fresh water, the impurity balance as presented in Equation 2 will not be achieved. Thus, we can conclude that there is an excess impurity load from sources located at the sink cumulative loads interval. To determine the actual amount of source 2 and the amount of fresh water added to sink 1 , it is assumed that $x$ amount of source 2 and $y$ amount of fresh water are added to sink 1 . The summation of the two amounts is 4200 ton/day according to the flowrate balance of sink 1 (Equation 1). Using equation 1 and 2 , sink 1 takes $23.657 \mathrm{~mol} / \mathrm{s}$ from source 2 and $4176.343 \mathrm{ton} /$ day from fresh water source. Note also that sink 1 completes its demand from the fresh water source rather than source 1. Because the fresh water source contains a higher impurity concentration than source 1 .

Sink 2 takes 307.8 ton/day from source 2 and completes its demand from the fresh water source (11692.2 ton/day). The last amount of fresh water is 8141.137 ton/day. This amount is sent to sink 3 . If sink 3 took this amount and 436.7418 ton/day from source 2 (column 8 and row 9 in Table 8) and completes its demand from source 1, the impurity concentration balance of sink 3 according to Equation 2 is not achieved. To achieve the impurity concentration balance, $x$ amount of source 2 and $y$ amount of source 1 are assumed to be supplied to sink 3 . Using Equations 1 and 2, it is found that, 483.605 ton/day from source 2 and 2575.258 ton/day from source 1 are sent to sink 3. The fresh water target is consumed, so sinks 4 and 5 take their demands from the sources located at their cumulative load intervals and source 1. 327.66 ton/day and 3276.6 ton/day from source 2 are sent to sink 4 and sink 
5 , respectively, and each of them completes its demand from source 1 . The pinch point divided source 2 to tow flowrates 4419.317 ton/day from source 2 is reuse/recycled in the region above the pinch and 10100.68 ton/day is discharged as wastewater below the pinch point concentration. Below the pinch point, there are not any sinks, so the flowrates of source 3 and 4 are discharged. Figure 2 is the network design of case study 2 .

Table 8:-Mass load cascade analysis for case study 2

\begin{tabular}{|c|c|c|c|c|c|c|c|c|c|c|c|}
\hline $\begin{array}{c}\text { Interval } \\
\mathrm{k}\end{array}$ & $\begin{array}{c}\text { Cumulative } \\
\text { load }\left(\mathrm{M}_{\mathrm{k}}\right) \\
(\mathrm{kg} / \mathrm{day})\end{array}$ & $\begin{array}{c}\text { Net } \\
\text { interval } \\
\text { Load } \\
\Delta \mathrm{M}_{\mathrm{k}} \\
(\mathrm{kg} / \text { day })\end{array}$ & $\begin{array}{c}\text { Process } \\
\text { sources } \\
\mathrm{SR}_{\mathrm{k}}\end{array}$ & $\begin{array}{l}\text { Source } \\
\text { conc. } \\
\text { CSR, k }\end{array}$ & $\begin{array}{c}\text { Process } \\
\text { Sinks } \\
\text { SK }_{k}\end{array}$ & $\begin{array}{l}\text { Sink } \\
\text { conc. } \\
\text { C SK, k }\end{array}$ & $\begin{array}{c}\text { Interval } \\
\text { Source } \\
\text { flowrate } \\
\Delta \mathrm{M}_{\mathrm{SR}, \mathrm{k}} \\
\text { (ton/day) }\end{array}$ & $\begin{array}{c}\text { Interval } \\
\text { Sink } \\
\text { flowrate } \\
\Delta \mathrm{M}_{\mathrm{SK}, \mathrm{k}} \\
\text { (ton/day) }\end{array}$ & $\begin{array}{c}\text { Net } \\
\text { flowrate } \\
\Delta \mathrm{S}_{\mathrm{k}} \\
\text { (ton/day) }\end{array}$ & $\begin{array}{c}\text { Cascade } \\
\text { net } \\
\text { flowrate } \\
\text { Cum } \Delta \mathrm{S}_{\mathrm{k}} \\
0 \\
0\end{array}$ & $\begin{array}{c}\text { Cascade } \\
\text { net } \\
\text { flowrate } \\
\text { Cum } \Delta Q_{k} \\
24009.68\end{array}$ \\
\hline \multirow[t]{2}{*}{1} & 0 & & & & & & & & & & \\
\hline & & -33.4782 & source 1 & 0 & $\operatorname{sink} 1$ & 5.5 & 7971 & -25752.5 & 33723.46 & 33723.46 & 57733.15 \\
\hline \multirow[t]{2}{*}{2} & -33.4782 & & source 1 & 0 & sink 1 & 5.5 & & & & & \\
\hline & & 38.9382 & source 2 & 235 & sink 1 & 5.5 & 168.7097 & 29952.46 & -29783.8 & 3939.71 & 27949.39 \\
\hline \multirow[t]{2}{*}{3} & 5.46 & & source 2 & 235 & sink 1 & 5.5 & & & & & \\
\hline & & 71.04 & source 2 & 235 & $\operatorname{sink} 2$ & 10.12 & 307.799 & 12000 & -11692.2 & $\begin{array}{l}-7752.49 \\
\end{array}$ & 16257.19 \\
\hline \multirow[t]{2}{*}{4} & 76.5 & & source 2 & 235 & $\operatorname{sink} 2$ & 10.12 & & & & & \\
\hline & & 100.8 & source 2 & 235 & $\operatorname{sink} 3$ & 13.2 & 436.7418 & 11200 & -10763.3 & -18515.7 & 5493.934 \\
\hline \multirow[t]{2}{*}{5} & 177.3 & & source 2 & 235 & $\operatorname{sink} 3$ & 13.2 & & & & & \\
\hline & & 68.6 & source 2 & 235 & $\operatorname{sink} 4$ & 38.5 & 297.227 & 2000 & -1702.77 & -20218.5 & 3791.161 \\
\hline \multirow[t]{2}{*}{6} & 245.9 & & source 2 & 235 & sink 4 & 38.5 & & & & & \\
\hline & & 740.6 & source 2 & 235 & sink 5 & 110 & 3208.839 & 7000 & -3791.16 & -24009.68 & $\begin{array}{c}7.73 E-12 \\
\text { (Pinch point) }\end{array}$ \\
\hline \multirow[t]{2}{*}{7} & 986.5 & & source 2 & 235 & sink 5 & 110 & & & & & \\
\hline & & 2331.238 & source 2 & 235 & & & 10100.68 & & 10100.68 & -13909 & 10100.68 \\
\hline \multirow[t]{2}{*}{8} & 3317.738 & & source 2 & 235 & & & & & & & \\
\hline & & 255.906 & source 3 & 275 & & & 945 & & 945 & -12964 & 11045.68 \\
\hline \multirow[t]{2}{*}{9} & 3573.644 & & source 3 & 275 & & & & & & & \\
\hline & & 6872.25 & source 4 & 504 & & & 13750 & & 13750 & 786 & 24795.68 \\
\hline 10 & 10445.89 & & source 4 & 504 & & & & & & & \\
\hline
\end{tabular}

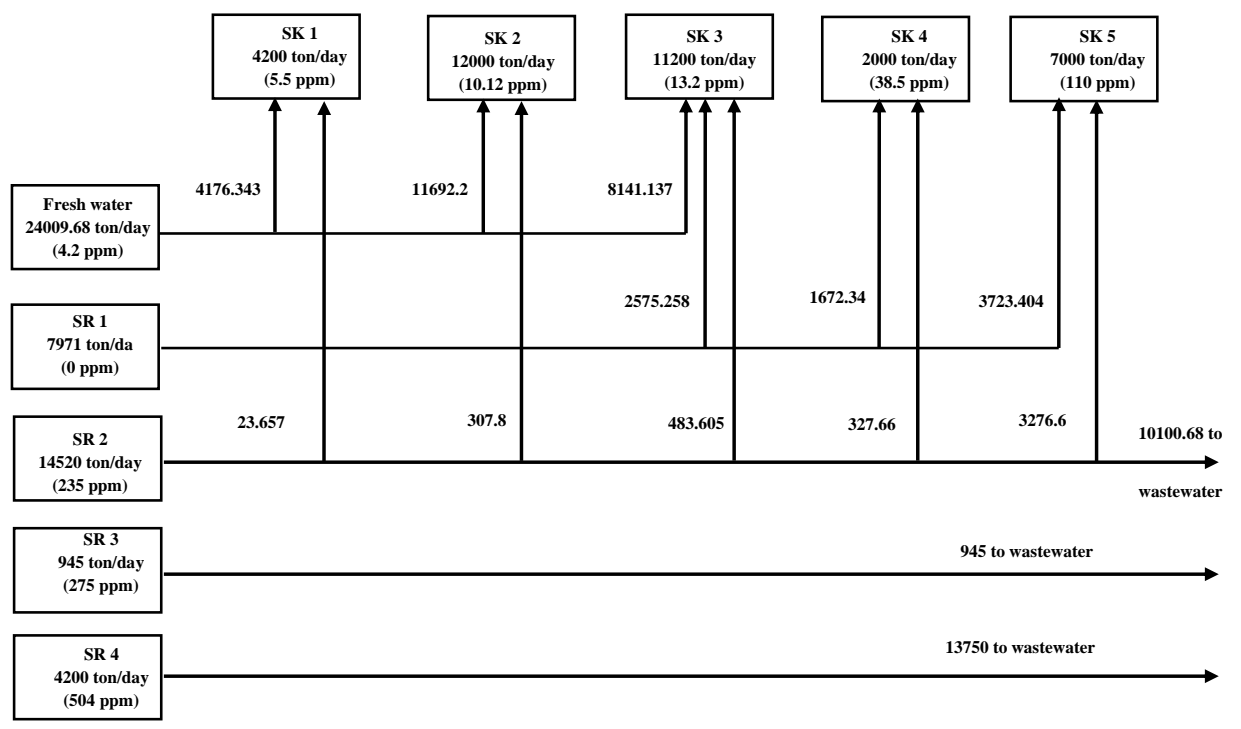

Figure 2:- Water network design for case study 2

\section{Mass Load Cascade Analysis for Regeneration of Hydrogen and Water Networks}

The regeneration system for hydrogen and water networks is another tool used to reduce the fresh utility flowrate after exhaustion of material recovery through reuse/recycle. It is modelled as single-pass regeneration system with single input feed stream and single product stream or partitioning regeneration system with single input feed stream and two product streams [32].

This section demonstrates how the MLCA technique is used to place a single-pass or partitioning regeneration system with pure or impure fresh utility in the context of the overall process. The MLCA for reuse/recycle is extended to determine the targets for hydrogen and water networks with regeneration system. As illustrated previously, minimum fresh utility flowrate, minimum discharge flowrate and pinch point location are the results of 
the mass load cascade analysis table for reuse/recycle integration system. To represent the problem as process regeneration a new mass load cascade analysis table is constructed. A regeneration unit at the pinch point $[29,33]$ is added to the hydrogen/water network. The following properties of the regeneration unit are used:

- It is assumed that the regeneration unit is located at the pinch point determined previously from the mass load cascade analysis table for reuse/recycle.

- The number of sinks is the same as used in recycle/reuse system.

- The number of sources is increased by one new source in case of single - pass regenerator (Figure 3, a) or by two new sources in case of partitioning regenerator (Figure 3, b).

- The regeneration flowrate is taken from the source located at the pinch point.

As shown in Figure 3 (a), the single-pass regeneration system has single inlet stream $\left(\mathrm{F}_{\text {regen }}\right)$ and single outlet stream $\left(F_{\text {out }}\right)$. The flowrate is assumed to be the same before and after the regeneration unit [10] as the water enters the unit with a high concentration of impurities $\left(\mathrm{C}_{\mathrm{in}}\right)$ and exits at a lower impurity concentration $\left(\mathrm{C}_{\mathrm{out}}\right)$. On the other hand, in the partitioning regeneration system (Figure $3, b)$, there are single input stream $\left(\mathrm{F}_{\text {regen }}\right)$ and two output streams of different quality, called a high quality top product stream $\left(\mathrm{F}_{\mathrm{t}}\right)$ at concentration $\mathrm{C}_{\mathrm{t}}$ and a lower quality bottom product stream $\left(\mathrm{F}_{\mathrm{b}}\right)$ at concentration $\mathrm{C}_{\mathrm{b}}$. The partitioning regeneration systems can be seen in pressure swing adsorption, membranes, filtration systems and gravitational settling systems, etc [10], [32].

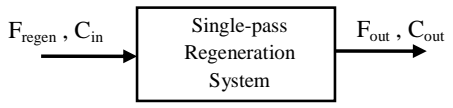

(a)

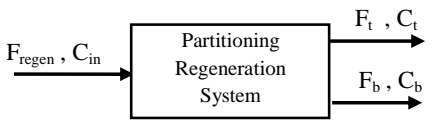

(b)

Figure 3:- (a) Single-pass regeneration system and (b) Partitioning regeneration system

In order to obtain the top flowrate, the bottom flowrate and the bottom concentration of the partitioning regenerator, Equations 4, 5 and 6 are applied to water network and Equations 4, 5 and 7 are applied to hydrogen network. Note that Equations 4 and 5 are the overall material balance and the overall impurity balance, respectively, while Equations 6 and 7 are associated with known fluid recovery factor $(\alpha)$.

$$
\begin{aligned}
& F_{\text {regen }}=F_{t}+F_{b} \\
& F_{\text {regen }} C_{i n}=F_{t} C_{t}+F_{b} C_{b} \\
& F_{\text {regen }} \alpha\left(10^{6}-C_{i n}\right)=F_{t}\left(10^{6}-C_{t}\right) \\
& F_{\text {regen }} \alpha\left(100-C_{\text {in }}\right)=F_{t}\left(100-C_{t}\right)
\end{aligned}
$$

Case study 3 : regeneration of water network (single-pass regeneration)

This case study is taken from Agrawal and Shenoy [33]. It involves 4 water sources and four water sinks as described in Table 9. The fresh source is supplied at zero impurity concentration. The MLCA tables for reuse/recycle are illustrated in Tables 10 and 11.

\begin{tabular}{|c|c|c|c|c|c|c|c|c|c|}
\hline $\begin{array}{l}\text { Sourcs } \\
\left(\mathrm{SR}_{, \mathrm{j}}\right)\end{array}$ & $\begin{array}{c}\begin{array}{c}\text { Flowrate } \\
\text { (ton/h) }\end{array} \\
\end{array}$ & $\begin{array}{c}\text { Concentration } \\
(\mathrm{ppm})\end{array}$ & $\begin{array}{c}\text { Load } \\
(\mathrm{kg} / \mathrm{h})\end{array}$ & $\begin{array}{c}\text { Cum load } \\
(\mathrm{kg} / \mathrm{h})\end{array}$ & $\begin{array}{l}\text { Sinks } \\
\left(\mathrm{SK}_{\mathrm{j}}\right) \\
\end{array}$ & $\begin{array}{c}\text { Flowrate } \\
\text { (ton/h) }\end{array}$ & $\begin{array}{c}\text { Concentration } \\
(\mathrm{ppm})\end{array}$ & $\begin{array}{l}\text { Load } \\
(\mathrm{kg} / \mathrm{h})\end{array}$ & $\begin{array}{c}\text { Cum load } \\
(\mathrm{kg} / \mathrm{h})\end{array}$ \\
\hline $\mathrm{SR}_{1}$ & 50 & 50 & 2.5 & 2.5 & $\mathrm{SK}_{1}$ & 50 & 20 & 1 & 1 \\
\hline $\mathrm{SR}_{2}$ & 100 & 100 & 10 & 12.5 & $\mathrm{SK}_{2}$ & 100 & 50 & 5 & 6 \\
\hline $\mathrm{SR}_{3}$ & 70 & 150 & 10.5 & 23 & $\mathrm{SK}_{3}$ & 80 & 100 & 8 & 14 \\
\hline $\mathrm{SR}_{4}$ & 60 & 250 & 15 & 38 & $\mathrm{SK}_{4}$ & 70 & 200 & 14 & 28 \\
\hline
\end{tabular}

Table 9:-Sources and Sinks data for case study 3

\begin{tabular}{|c|c|c|c|c|c|}
\hline Sources & Flowrate, $($ ton $/ \mathrm{h})$ & Concentration, $(\mathrm{ppm})$ & Sinks & Flowrate, (ton/h) & Conc., $(\mathrm{ppm})$ \\
\hline 1 & 50 & 50 & 1 & 20 & 50 \\
\hline 2 & 100 & 100 & 2 & 100 & 50 \\
\hline 3 & 70 & 150 & 3 & 80 & 100 \\
\hline 4 & 60 & 250 & 4 & 70 & 200 \\
\hline
\end{tabular}

Table 10:-Sources and sinks cumulative loads (reuse/recycle) for case study 3 
As described in Table 11, the minimum fresh water and the wastewater targets are $70 \mathrm{ton} / \mathrm{h}$ and 50 ton/h, respectively. The pinch point is located at the concentration of source 3 (150 ppm) [33].

Table 11:-Mass load cascade analysis for reuse/recycle of case study 3

\begin{tabular}{|c|c|c|c|c|c|c|c|c|c|c|c|}
\hline $\begin{array}{c}\text { Interval } \\
\mathrm{k}\end{array}$ & $\begin{array}{c}\text { Cumulative } \\
\text { load }\left(\mathrm{M}_{\mathrm{k}}\right) \\
(\mathrm{kg} / \mathrm{h})\end{array}$ & $\begin{array}{c}\text { Net } \\
\text { interval } \\
\text { Load } \\
\Delta \mathrm{M}_{\mathrm{k}} \\
(\mathrm{kg} / \mathrm{h})\end{array}$ & $\begin{array}{c}\text { Process } \\
\text { sources } \\
\mathrm{SR}_{\mathrm{k}}\end{array}$ & $\begin{array}{l}\text { Source } \\
\text { conc. } \\
\text { CSRR,k }\end{array}$ & $\begin{array}{c}\text { Process } \\
\text { Sinks } \\
\text { SK }_{k}\end{array}$ & $\begin{array}{l}\text { Sink } \\
\text { conc. } \\
\text { CSK, }\end{array}$ & $\begin{array}{l}\text { Interval } \\
\text { Source } \\
\text { flowrate } \\
\Delta \mathrm{M}_{\mathrm{SR}, \mathrm{k}} \\
\text { (ton/h) }\end{array}$ & $\begin{array}{c}\text { Interval } \\
\text { Sink } \\
\text { flowrate } \\
\Delta \mathrm{M}_{\mathrm{SK}, \mathrm{k}} \\
\text { (ton/h) }\end{array}$ & $\begin{array}{c}\text { Net } \\
\text { flowrate } \\
\Delta \mathrm{S}_{\mathrm{k}} \\
(\operatorname{ton} / \mathrm{h})\end{array}$ & $\begin{array}{c}\text { Cascade } \\
\text { net } \\
\text { flowrate } \\
\text { Cum } \Delta \mathrm{S}_{\mathrm{k}} \\
0 \\
0\end{array}$ & $\begin{array}{c}\text { Cascade } \\
\text { net } \\
\text { flowrate } \\
\text { Cum } \Delta \mathrm{Q}_{\mathrm{k}} \\
70 \\
70\end{array}$ \\
\hline \multirow[t]{2}{*}{1} & 0 & & & & & & & & & & \\
\hline & & 1 & source 1 & 50 & $\begin{array}{l}\operatorname{sink} 1 \\
\end{array}$ & 20 & 20 & 50 & -30 & -30 & 40 \\
\hline \multirow[t]{2}{*}{2} & 1 & & source 1 & 50 & sink 1 & 20 & & & & & \\
\hline & & 1.5 & source 1 & 50 & sink 2 & 50 & 30 & 30 & 0 & -30 & 40 \\
\hline \multirow[t]{2}{*}{3} & 2.5 & & source 1 & 50 & sink 2 & 50 & & & & & \\
\hline & & 3.5 & source 2 & 100 & sink 2 & 50 & 35 & 70 & -35 & -65 & 5 \\
\hline \multirow[t]{2}{*}{4} & 6 & & source 2 & 100 & sink 2 & 50 & & & & & \\
\hline & & 6.5 & source 2 & 100 & $\begin{array}{l}\operatorname{sink} 3 \\
\end{array}$ & 100 & 65 & 65 & 0 & -65 & 5 \\
\hline \multirow[t]{2}{*}{5} & 12.5 & & source 2 & 100 & $\begin{array}{l}\operatorname{sink} 3 \\
\end{array}$ & 100 & & & & & \\
\hline & & 1.5 & source 3 & 150 & sink 3 & 100 & 10 & 15 & -5 & -70 & 0 \\
\hline \multirow[t]{2}{*}{6} & 14 & & source 3 & 150 & sink 3 & 100 & & & & & \\
\hline & & 9 & source 3 & 150 & $\operatorname{sink} 4$ & 200 & 60 & 45 & 15 & -55 & 15 \\
\hline \multirow[t]{2}{*}{7} & 23 & & source 3 & 150 & sink 4 & 200 & & & & & \\
\hline & & 5 & source 4 & 250 & sink 4 & 200 & 20 & 25 & -5 & -60 & 10 \\
\hline \multirow[t]{2}{*}{8} & 28 & & source 4 & 250 & sink 4 & 200 & & & & & \\
\hline & & 10 & source 4 & 250 & & & & 40 & & 40 & 50 \\
\hline 9 & 38 & & source 4 & 250 & & & & & & & \\
\hline
\end{tabular}

To incorporate a single-pass regeneration system of fixed outlet concentration at $20 \mathrm{ppm}\left(\mathrm{C}_{\mathrm{out}}=20 \mathrm{ppm}\right)$ in the MLCA, it is assumed that the wastewater from reuse/recycle which is $50 \mathrm{ton} / \mathrm{h}$ is regenerated at the pinch concentration. Thus, this flowrate is included in the network as a new source and source 3 is decreased by an amount equals the wastewater flowrate. The MLCA tables are constructed as described in Tables 12 and 13.

Table 12:-Sources and Sinks cumulative loads (regeneration)

\begin{tabular}{|c|c|c|c|c|c|c|c|c|c|}
\hline $\begin{array}{c}\text { Sourcs } \\
\left(S R_{, j}\right)\end{array}$ & $\begin{array}{c}\text { Flowrate } \\
\text { (ton/h) }\end{array}$ & $\begin{array}{l}\text { Conc. } \\
\text { (ppm) }\end{array}$ & $\begin{array}{c}\text { Load } \\
(\mathrm{kg} / \mathrm{h})\end{array}$ & $\begin{array}{c}\text { Cum load } \\
(\mathrm{kg} / \mathrm{h})\end{array}$ & $\begin{array}{l}\text { Sinks } \\
\left(\mathrm{SK}_{, \mathrm{j}}\right)\end{array}$ & $\begin{array}{c}\text { Flowrate } \\
\text { (ton/h) }\end{array}$ & $\begin{array}{l}\text { Conc. } \\
\text { (ppm) }\end{array}$ & $\begin{array}{c}\text { Load } \\
(\mathrm{kg} / \mathrm{h})\end{array}$ & $\begin{array}{c}\text { Cum load } \\
(\mathrm{kg} / \mathrm{h})\end{array}$ \\
\hline Out of regen. & 50 & 20 & 1 & 1 & $\mathrm{SK}_{1}$ & 50 & 20 & 1 & 1 \\
\hline $\mathrm{SR}_{1}$ & 50 & 50 & 2.5 & 3.5 & $\mathrm{SK}_{2}$ & 100 & 50 & 5 & 6 \\
\hline $\mathrm{SR}_{2}$ & 100 & 100 & 10 & 13.5 & $\mathrm{SK}_{3}$ & 80 & 100 & 8 & 14 \\
\hline $\mathrm{SR}_{3}$ & 20 & 150 & 3 & 16.5 & $\mathrm{SK}_{4}$ & 70 & 200 & 14 & 28 \\
\hline $\mathrm{SR}_{4}$ & 60 & 250 & 15 & 31.5 & & & & & \\
\hline
\end{tabular}

Table 13:-Mass load cascade analysis for case study 3 (regeneration with $\mathrm{F}_{\text {regen }}=\mathrm{F}_{\text {wastertweter }}$ )

\begin{tabular}{|c|c|c|c|c|c|c|c|c|c|c|c|}
\hline $\begin{array}{c}\text { Interval } \\
\mathrm{k}\end{array}$ & $\begin{array}{c}\text { Cumulative } \\
\text { load }\left(\mathrm{M}_{\mathrm{k}}\right) \\
(\mathrm{kg} / \mathrm{h})\end{array}$ & $\begin{array}{c}\text { Net } \\
\text { interval } \\
\text { Load } \\
\Delta \mathrm{M}_{\mathrm{k}} \\
(\mathrm{kg} / \mathrm{h})\end{array}$ & $\begin{array}{c}\text { Process } \\
\text { sources } \\
\text { SR }_{k}\end{array}$ & $\begin{array}{l}\text { Source } \\
\text { conc. } \\
\text { C }_{\mathrm{SR}, \mathrm{k}}\end{array}$ & $\begin{array}{l}\text { Process } \\
\text { Sinks } \\
\text { SK }_{k}\end{array}$ & $\begin{array}{l}\text { Sink } \\
\text { conc. } \\
\text { C SK, }\end{array}$ & $\begin{array}{l}\text { Interval } \\
\text { Source } \\
\text { flowrate } \\
\Delta \mathrm{M}_{\mathrm{SR}, \mathrm{k}} \\
\text { (ton/h) }\end{array}$ & $\begin{array}{l}\text { Interval } \\
\text { Sink } \\
\text { flowrate } \\
\Delta \mathrm{M}_{\mathrm{SK}, \mathrm{k}} \\
\text { (ton/h) }\end{array}$ & $\begin{array}{c}\text { Net } \\
\text { flowrate } \\
\Delta \mathrm{S}_{\mathrm{k}} \\
\text { (ton/h) }\end{array}$ & $\begin{array}{c}\text { Cascade } \\
\text { net } \\
\text { flowrate } \\
\text { Cum } \Delta \mathrm{S}_{\mathrm{k}} \\
0 \\
0\end{array}$ & $\begin{array}{c}\text { Cascade } \\
\text { net } \\
\text { flowrate } \\
\text { Cum } \Delta \mathrm{Q}_{\mathrm{k}} \\
34\end{array}$ \\
\hline \multirow[t]{2}{*}{1} & 0 & & & & & & & & & & \\
\hline & & 1 & $\begin{array}{c}\text { Out of } \\
\text { regeneration }\end{array}$ & 20 & $\operatorname{sink} 1$ & 20 & 50 & 50 & 0 & 0 & 34 \\
\hline \multirow[t]{2}{*}{2} & 1 & & $\begin{array}{c}\text { Out of } \\
\text { regeneration }\end{array}$ & 20 & sink 1 & 20 & & & & & \\
\hline & & 2.5 & source 1 & 50 & $\operatorname{sink} 2$ & 50 & 50 & 50 & 0 & 0 & 34 \\
\hline \multirow[t]{2}{*}{3} & 3.5 & & source 1 & 50 & $\operatorname{sink} 2$ & 50 & & & & & \\
\hline & & 2.5 & source 2 & 100 & $\operatorname{sink} 2$ & 50 & 25 & 50 & -25 & -25 & 9 \\
\hline \multirow[t]{2}{*}{4} & 6 & & source 2 & 100 & $\operatorname{sink} 2$ & 50 & & & & & \\
\hline & & 7.5 & source 2 & 100 & $\operatorname{sink} 3$ & 100 & 75 & 75 & 0 & -25 & 9 \\
\hline \multirow[t]{2}{*}{5} & 13.5 & & source 2 & 100 & $\operatorname{sink} 3$ & 100 & & & & & \\
\hline & & 0.5 & source 3 & 150 & $\operatorname{sink} 3$ & 100 & 3.3333 & 5 & -1.6667 & -26.6667 & 7.3333 \\
\hline \multirow[t]{2}{*}{6} & 14 & & source 3 & 150 & $\operatorname{sink} 3$ & 100 & & & & & \\
\hline & & 2.5 & source 3 & 150 & $\operatorname{sink} 4$ & 200 & 16.6667 & 12.5 & 4.16666 & -22.5 & 11.5 \\
\hline \multirow[t]{2}{*}{7} & 16.5 & & source 3 & 150 & sink 4 & 200 & & & & & \\
\hline & & 11.5 & source 4 & 250 & $\operatorname{sink} 4$ & 200 & 46 & 57.5 & -11.5 & -34 & 0 \\
\hline \multirow[t]{2}{*}{8} & 28 & & source 4 & 250 & sink 4 & 200 & & & & & \\
\hline & & 3.5 & source 4 & 250 & & & 14 & & 14 & & 14 \\
\hline 9 & 31.5 & & source 4 & 250 & & & & & & & \\
\hline
\end{tabular}


As shown in Table 13, the minimum fresh water and wastewater discharge are decreased to 34 and 14 ton/h respectively. Table 14 is another MLCA when all the flowrate of source 3 at the pinch concentration is regenerated. It is noted that $23.6 \mathrm{ton} / \mathrm{h}$ fresh water is required, whereas $3.6 \mathrm{ton} / \mathrm{h}$ of wastewater is discharged. The high reduction in the fresh water required and the wastewater discharge is based on the regenerated flowrate. Choice between regeneration an amount equals the wastewater or increasing this amount to be all the source at the pinch depends on the cost of the fresh water when compared to the cost of the regenerated flowrate. Another regeneration system assumed by Agrawal and Shenoy [33] is presented in MLCA Table 15. They assume that 28.856 ton/h from source 3 is regenerated. The minimum fresh water and wastewater calculated by MLCA are identical to their results. The water optimum network design is described in Figure 3.

Table 14:-Mass load cascade analysis for case study 3 (regeneration with $\mathrm{F}_{\text {regen }}=$ total flowrate of $\mathrm{F}_{\mathrm{SR}, 3}$ )

\begin{tabular}{|c|c|c|c|c|c|c|c|c|c|c|c|}
\hline $\begin{array}{c}\text { Interval } \\
\mathrm{k}\end{array}$ & $\begin{array}{c}\text { Cumulative } \\
\text { load }\left(\mathrm{M}_{\mathrm{k}}\right) \\
(\mathrm{kg} / \mathrm{h})\end{array}$ & $\begin{array}{c}\text { Net } \\
\text { interval } \\
\text { Load } \\
\Delta \mathrm{M}_{\mathrm{k}} \\
(\mathrm{kg} / \mathrm{h})\end{array}$ & $\begin{array}{c}\text { Process } \\
\text { sources } \\
\mathrm{SR}_{\mathrm{k}}\end{array}$ & $\begin{array}{c}\text { Source } \\
\text { conc. } \\
\text { C }_{\mathrm{SR}, \mathrm{k}}\end{array}$ & $\begin{array}{c}\text { Process } \\
\text { Sinks } \\
\text { SK }_{k}\end{array}$ & $\begin{array}{l}\text { Sink } \\
\text { conc. } \\
\text { C SK, k }\end{array}$ & $\begin{array}{c}\text { Interval } \\
\text { Source } \\
\text { flowrate } \\
\Delta \mathrm{M}_{\mathrm{SR}, \mathrm{k}} \\
\text { (ton/h) }\end{array}$ & $\begin{array}{c}\text { Interval } \\
\text { Sink } \\
\text { flowrate } \\
\Delta \mathrm{M}_{\mathrm{SK}, \mathrm{k}} \\
\text { (ton/h) }\end{array}$ & $\begin{array}{c}\text { Net } \\
\text { flowrate } \\
\Delta \mathrm{S}_{\mathrm{k}} \\
(\operatorname{ton} / \mathrm{h})\end{array}$ & $\begin{array}{c}\text { Cascade } \\
\text { net } \\
\text { flowrate } \\
\text { Cum } \Delta \mathrm{S}_{\mathrm{k}} \\
0 \\
0\end{array}$ & $\begin{array}{c}\begin{array}{c}\text { Cascade } \\
\text { net } \\
\text { flowrate } \\
\text { Cum } \Delta \mathrm{Q}_{\mathrm{k}} \\
23.6\end{array} \\
\end{array}$ \\
\hline \multirow[t]{2}{*}{1} & 0 & & & & & & & & & & \\
\hline & & 1 & $\begin{array}{c}\text { Out of } \\
\text { regeneration }\end{array}$ & 20 & $\operatorname{sink} 1$ & 20 & 50 & 50 & 0 & 0 & 23.6 \\
\hline \multirow[t]{2}{*}{2} & 1 & & $\begin{array}{c}\text { Out of } \\
\text { regeneration }\end{array}$ & 20 & $\operatorname{sink} 1$ & 20 & & & & & \\
\hline & & 0.4 & $\begin{array}{c}\text { Out of } \\
\text { regeneration }\end{array}$ & 20 & $\operatorname{sink} 2$ & 50 & 20 & 8 & 12 & 12 & 35.6 \\
\hline \multirow[t]{2}{*}{3} & 1.4 & & $\begin{array}{c}\text { Out of } \\
\text { regeneration }\end{array}$ & 20 & $\operatorname{sink} 2$ & 50 & & & & & \\
\hline & & 2.5 & source 1 & 50 & sink 2 & 50 & 50 & 50 & 0 & 12 & 35.6 \\
\hline \multirow[t]{2}{*}{4} & 3.9 & & source 1 & 50 & $\operatorname{sink} 2$ & 50 & & & & & \\
\hline & & 2.1 & source 2 & 100 & $\operatorname{sink} 2$ & 50 & 21 & 42 & -21 & -9 & 14.6 \\
\hline \multirow[t]{2}{*}{5} & 6 & & $\begin{array}{l}\text { source } 2 \\
\end{array}$ & 100 & $\operatorname{sink} 2$ & 50 & & & & & \\
\hline & & 7.9 & source 2 & 100 & $\operatorname{sink} 3$ & 100 & 79 & 79 & 0 & -9 & 14.6 \\
\hline \multirow[t]{2}{*}{6} & 13.9 & & source 2 & 100 & sink 3 & 100 & & & & & \\
\hline & & 0.1 & source 4 & 250 & $\begin{array}{l}\operatorname{sink} 3 \\
\end{array}$ & 100 & 0.4 & 1 & $\begin{array}{l}-0.6 \\
\end{array}$ & $\begin{array}{l}-9.6 \\
\end{array}$ & 14 \\
\hline \multirow[t]{2}{*}{7} & 14 & & source 4 & 250 & sink 3 & 100 & & & & & \\
\hline & & 14 & source 4 & 250 & sink 4 & 200 & 56 & 70 & -14 & -23.6 & 0 \\
\hline \multirow[t]{2}{*}{8} & 28 & & source 4 & 250 & sink 4 & 200 & & & & & \\
\hline & & 0.9 & source 4 & 250 & & & 3.6 & & 3.6 & -20 & 3.6 \\
\hline 9 & 28.9 & & source 4 & 250 & & & & & & & \\
\hline
\end{tabular}

Table 15:-Mass load cascade analysis for case study 3 (regeneration with $\mathrm{F}_{\text {regen }}=28.846 \mathrm{t} / \mathrm{h}$ of $\mathrm{F}_{\mathrm{SR}, 3}$ )

\begin{tabular}{|c|c|c|c|c|c|c|c|c|c|c|c|}
\hline $\begin{array}{c}\text { Inter } \\
\text { val } \\
\mathrm{k}\end{array}$ & $\begin{array}{c}\text { Cumulative } \\
\text { load } \\
\left(\mathrm{M}_{\mathrm{k}}\right) \\
(\mathrm{kg} / \mathrm{h})\end{array}$ & $\begin{array}{c}\text { Net } \\
\text { interval } \\
\text { Load } \\
\Delta \mathrm{M}_{\mathrm{k}} \\
(\mathrm{kg} / \mathrm{h})\end{array}$ & $\begin{array}{c}\text { Process } \\
\text { sources } \\
\mathrm{SR}_{\mathrm{k}}\end{array}$ & $\begin{array}{l}\text { Source } \\
\text { conc. } \\
\text { C }_{\mathrm{SR}, \mathrm{k}}\end{array}$ & $\begin{array}{c}\text { Process } \\
\text { Sinks } \\
\text { SK }_{k}\end{array}$ & $\begin{array}{l}\text { Sink } \\
\text { conc. } \\
\text { C }_{\text {SK, }}\end{array}$ & $\begin{array}{c}\text { Interval } \\
\text { Source } \\
\text { flowrate } \\
\Delta \mathrm{M}_{\mathrm{SR}, \mathrm{k}} \\
\text { (ton/h) }\end{array}$ & $\begin{array}{l}\text { Interval } \\
\text { Sink } \\
\text { flowrate } \\
\Delta \mathrm{M}_{\mathrm{SK}, \mathrm{k}} \\
\text { (ton/h) }\end{array}$ & $\begin{array}{c}\text { Net } \\
\text { flowrate } \\
\Delta \mathrm{S}_{\mathrm{k}} \\
\text { (ton } / \mathrm{h} \text { ) }\end{array}$ & $\begin{array}{c}\text { Cascade } \\
\text { Net } \\
\text { flowrate } \\
\text { Cum } \Delta \mathrm{S}_{\mathrm{k}} \\
0 \\
0\end{array}$ & 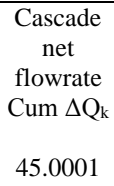 \\
\hline \multirow[t]{2}{*}{1} & 0 & & & & & & & & & & \\
\hline & & 0.57692 & $\begin{array}{c}\text { Out of } \\
\text { regeneration }\end{array}$ & 20 & sink 1 & 20 & 28.846 & 28.846 & 0 & 0 & 45.0001 \\
\hline \multirow[t]{2}{*}{2} & 0.57692 & & $\begin{array}{c}\text { Out of } \\
\text { regeneration }\end{array}$ & 20 & sink 1 & 20 & & & & & \\
\hline & & 0.42308 & source 1 & 50 & sink 1 & 20 & 8.4616 & 21.154 & -12.6924 & -12.6924 & 32.30768 \\
\hline \multirow[t]{2}{*}{3} & 1 & & source 1 & 50 & sink 1 & 20 & & & & & \\
\hline & & 2.07692 & source 1 & 50 & sink 2 & 50 & 41.5384 & 41.5384 & 0 & -12.6924 & 32.30768 \\
\hline \multirow[t]{2}{*}{4} & 3.07692 & & source 1 & 50 & sink 2 & 50 & & & & & \\
\hline & & 2.92308 & source 2 & 100 & sink 2 & 50 & 29.2308 & 58.4616 & -29.2308 & -41.9232 & 3.07688 \\
\hline \multirow[t]{2}{*}{5} & 6 & & source 2 & 100 & sink 2 & 50 & & & & & \\
\hline & & 7.07692 & source 2 & 100 & sink 3 & 100 & 70.7692 & 70.7692 & 0 & -41.9232 & 3.07688 \\
\hline \multirow[t]{2}{*}{6} & 13.07692 & & source 2 & 100 & sink 3 & 100 & & & & & \\
\hline & & 0.92308 & source 3 & 150 & sink 3 & 100 & 6.153867 & 9.2308 & -3.07693 & -45.0001 & $-5.3 \mathrm{E}-05$ \\
\hline \multirow[t]{2}{*}{7} & 14 & & source 3 & 150 & sink 3 & 100 & & & & & \\
\hline & & 5.25002 & source 3 & 150 & sink 4 & 200 & 35.00013 & 26.2501 & 8.750033 & -36.2501 & 8.74998 \\
\hline \multirow[t]{2}{*}{8} & 19.25002 & & source 3 & 150 & sink 4 & 200 & & & & & \\
\hline & & 8.74998 & source 4 & 250 & & & 34.99992 & 43.7499 & -8.74998 & -45.0001 & 0 \\
\hline \multirow[t]{3}{*}{9} & 28 & & source 4 & 250 & & & & & & & \\
\hline & & 6.25002 & source 4 & 250 & & & 25.00008 & & 25.00008 & -20 & 25.00008 \\
\hline & 34.25002 & & source 4 & 250 & & & & & & & \\
\hline
\end{tabular}




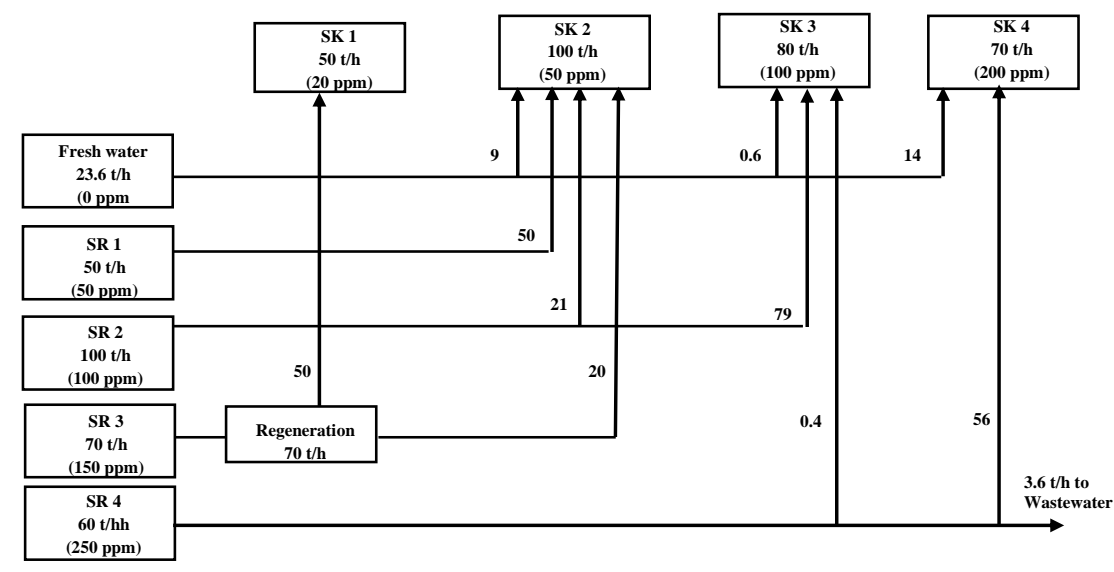

Figure 4:- Water network design for case study 3 with single-pass regeneration system

\section{Case study 4: regeneration of hydrogen network (partitioning regeneration)}

The same example for hydrogen network presented in case study 1 is resolved to further reduce the fresh hydrogen by using a gas separation membrane with hydrogen recovery of $95 \%(\alpha)$ and a product stream at $2 \%\left(\mathrm{C}_{\mathrm{t}}\right)$ impurity concentration [29], [32, [34]. By using equations 4, 5 and 7, the top product flowrate, the bottom product flowrate and the bottom impurity concentration of the membrane separation system are $69.57 \mathrm{~mol} / \mathrm{s}, 32.95 \mathrm{~mol} / \mathrm{s}$ and 89.11 mol\%, respectively. The two output streams of the membrane separation system are used in the MLCA as two new sources. In addition, the source flowrate at the pinch concentration is reduced to $354.879 \mathrm{~mol} / \mathrm{s}$. The MLCA tables are presented in Tables 16, and 17.

Table 16:-Sources and sinks cumulative loads for partitioning regeneration for case study 4 using membrane separation system

\begin{tabular}{|c|c|c|c|c|c|c|c|c|c|}
\hline $\begin{array}{l}\text { Sources } \\
(\mathrm{SR}, \mathrm{j})\end{array}$ & $\begin{array}{c}\begin{array}{c}\text { Flowrate } \\
(\mathrm{mol} / \mathrm{s})\end{array} \\
\end{array}$ & $\begin{array}{l}\text { Conc. } \\
(\mathrm{mol} \%)\end{array}$ & $\begin{array}{c}\begin{array}{c}\text { Load } \\
(\mathrm{mol} / \mathrm{s})\end{array} \\
\end{array}$ & $\begin{array}{c}\text { Cum load } \\
(\mathrm{mol} / \mathrm{s})\end{array}$ & $\begin{array}{l}\text { Sinks } \\
\left(\mathrm{SK}_{\mathrm{j}}\right)\end{array}$ & $\begin{array}{c}\begin{array}{c}\text { Flowrate } \\
(\mathrm{mol} / \mathrm{s})\end{array} \\
\end{array}$ & $\begin{array}{l}\text { Conc. } \\
(\mathrm{mol} \%)\end{array}$ & $\begin{array}{c}\begin{array}{c}\text { Load } \\
(\mathrm{mol} / \mathrm{s})\end{array} \\
\end{array}$ & $\begin{array}{c}\text { Cum load } \\
(\mathrm{mol} / \mathrm{s})\end{array}$ \\
\hline Membrane top & 69.57 & 2 & -2.0871 & -2.0871 & $\mathrm{HCU}$ & 2495 & 19.39 & 359.0305 & 359.0305 \\
\hline SRU & 623.8 & 7 & 12.476 & 10.3889 & NHT & 180.2 & 21.15 & 29.1023 & 388.1328 \\
\hline $\mathrm{CRU}$ & 415.8 & 20 & 62.37 & 72.7589 & DHT & 554.4 & 22.43 & 96.63192 & 484.7647 \\
\hline $\mathrm{HCU}$ & 1801.9 & 25 & 360.38 & 433.1389 & CNHT & 720.7 & 24.86 & 143.131 & 627.8957 \\
\hline NHT & 138.6 & 25 & 27.72 & 460.8589 & & & & & \\
\hline DHT & 346.5 & 27 & 76.23 & 537.0889 & & & & & \\
\hline CNHT & 354.879 & 30 & 88.71975 & 625.80865 & & & & & \\
\hline Membrane bottom & 32.95 & 89.11 & 27.71425 & 653.5229 & & & & & \\
\hline
\end{tabular}

As presented in Table 17, the fresh and discharge hydrogen flowrates are reduced to $196.77 \mathrm{~mol} / \mathrm{s}$ and 30.4686 $\mathrm{mol} / \mathrm{s}$, respectively. A new location of pinch exists at the bottom membrane concentration $(89.11 \mathrm{~mol} \%)$. Another option for this hydrogen network is to use a pressure swing adsorption (PSA) as a regenerator instead of the membrane separation. PSA is used at hydrogen recovery of $90 \%$ and a top product stream at 0.1 mol\% impurity concentration [29], [34]. Using the material balance for the partitioning regeneration system, it is found that, the top product flowrate is $64.65 \mathrm{~mol} / \mathrm{s}$ and the bottom product flowrate and its impurity concentration are calculated as $37.87 \mathrm{~mol} / \mathrm{s}$ and $81.01 \mathrm{~mol} \%$, respectively. MLCA tables are reconstructed for this hydrogen network using the PSA as a regenerator and the results are illustrated in Tables 18 . The fresh hydrogen is reduced from $268.821 \mathrm{~mol} / \mathrm{s}$ in case of reuse/recycle to $200.005 \mathrm{~mol} / \mathrm{s}$ in the regeneration by using the PSA. Also, the hydrogen discharge is reduced from $102.521 \mathrm{~mol} / \mathrm{s}$ to $33.705 \mathrm{~mol} / \mathrm{s}$ and the pinch point is increased to the bottom concentration of the PSA at $81.05 \mathrm{~mol} \%$.

From the above results, we conclude that regeneration using membrane is more useful than regeneration using PSA. These results are agreed with those presented in literature [29]. The network design with membrane separation is shown in Figure 4. Note that, in this network, the fresh hydrogen source has impurity concentration (5 mol\%) higher than one of the sources (top product of the membrane regeneration system). In designing the network, each sink will take its demand from the sources located at its cumulative loads interval and sources residual from the above cumulative loads intervals. If the sources and the sources residual are less than the sink demand, the sink completes 
its demand from the fresh hydrogen source. After consuming of the fresh hydrogen target, sinks will complete their demand from the top product of the membrane which is more pure ( $2 \mathrm{~mol} \%$ impurity concentration)) than the fresh hydrogen source.

Table 17:-Mass load cascade analysis for case study 4 with regeneration by using membrane separation system

\begin{tabular}{|c|c|c|c|c|c|c|c|c|c|c|c|}
\hline $\begin{array}{c}\text { Interval } \\
\mathrm{k}\end{array}$ & $\begin{array}{c}\text { Cumulative } \\
\text { load } \\
\left(\mathrm{M}_{\mathrm{k}}\right) \\
(\mathrm{mol} / \mathrm{s})\end{array}$ & $\begin{array}{c}\text { Net } \\
\text { interval } \\
\text { Load } \\
\Delta \mathrm{M}_{\mathrm{k}} \\
(\mathrm{mol} / \mathrm{s})\end{array}$ & $\begin{array}{c}\text { Process } \\
\text { sources } \\
\mathrm{SR}_{\mathrm{k}}\end{array}$ & $\begin{array}{l}\text { Source } \\
\text { conc. } \\
\text { C }_{\mathrm{SR}, \mathrm{k}}\end{array}$ & $\begin{array}{c}\text { Process } \\
\text { Sinks } \\
\text { SK }_{k}\end{array}$ & $\begin{array}{l}\text { Sink } \\
\text { conc. } \\
\text { C }_{\text {SK, },}\end{array}$ & $\begin{array}{l}\text { Interval } \\
\text { Source } \\
\text { flowrate } \\
\Delta \mathrm{M}_{\mathrm{sR}, \mathrm{k}} \\
(\mathrm{mol} / \mathrm{s})\end{array}$ & $\begin{array}{l}\begin{array}{l}\text { Interval } \\
\text { Sink } \\
\text { flowrate } \\
\Delta \mathrm{M}_{\mathrm{sK}, \mathrm{k}} \\
(\mathrm{mol} / \mathrm{s})\end{array}\end{array}$ & $\begin{array}{c}\text { Net } \\
\text { flowrate } \\
\Delta \mathrm{S}_{\mathrm{k}} \\
(\mathrm{mol} / \mathrm{s})\end{array}$ & $\begin{array}{c}\text { Cascade } \\
\text { net } \\
\text { flowrate } \\
\text { Cum } \Delta \mathrm{S}_{\mathrm{k}} \\
0 \\
0\end{array}$ & $\begin{array}{c}\begin{array}{c}\text { Cascade } \\
\text { net } \\
\text { flowrate }\end{array} \\
\text { Cum } \Delta \mathrm{Q}_{\mathrm{k}} \\
196.77\end{array}$ \\
\hline \multirow[t]{2}{*}{1} & 0 & & & & & & & & & & \\
\hline & & -2.087 & Memb. top & 2 & $\operatorname{sink} 1$ & 19.39 & 69.57 & -14.5 & 84.0738 & 84.0738 & 280.843 \\
\hline \multirow[t]{2}{*}{2} & -2.0871 & & Memb. top & 2 & $\operatorname{sink} 1$ & 19.39 & & & & & \\
\hline & & 12.476 & source 1 & 7 & sink 1 & 19.39 & 623.8 & 86.699 & 537.101 & 621.175 & 817.944 \\
\hline \multirow[t]{2}{*}{3} & 10.3889 & & source 1 & 7 & $\operatorname{sink} 1$ & 19.39 & & & & & \\
\hline & & 62.37 & source 2 & 20 & sink 1 & 19.39 & 415.8 & 433.43 & -17.626 & 603.549 & 800.318 \\
\hline \multirow[t]{2}{*}{4} & 72.7589 & & source 2 & 20 & sink 1 & 19.39 & & & & & \\
\hline & & 286.27 & source 3 & 25 & sink 1 & 19.39 & 1431.4 & 1989.4 & $\begin{array}{l}-558.02 \\
\end{array}$ & 45.528 & 242.298 \\
\hline \multirow[t]{2}{*}{5} & 359.031 & & source 3 & 25 & sink 1 & 19.39 & & & & & \\
\hline & & 29.102 & source 3 & 25 & $\operatorname{sink} 2$ & 21.15 & 145.51 & 180.2 & $\begin{array}{l}-34.689 \\
\end{array}$ & 10.8395 & 207.609 \\
\hline \multirow[t]{2}{*}{6} & 388.133 & & source 3 & 25 & $\operatorname{sink} 2$ & 21.15 & & & & & \\
\hline & & 45.006 & source 3 & 25 & $\operatorname{sink} 3$ & 22.43 & 225.03 & 258.21 & -33.18 & -22.341 & 174.429 \\
\hline \multirow[t]{2}{*}{7} & 433.139 & & source 3 & 25 & $\operatorname{sink} 3$ & 22.43 & 0 & & & & \\
\hline & & 27.72 & source 4 & 25 & $\operatorname{sink} 3$ & 22.43 & 138.6 & 159.04 & -20.436 & -42.777 & 153.993 \\
\hline \multirow[t]{2}{*}{8} & 460.859 & & source 4 & 25 & $\operatorname{sink} 3$ & 22.43 & & & & & \\
\hline & & 23.906 & source 5 & 27 & $\operatorname{sink} 3$ & 22.43 & 108.66 & 137.15 & -28.49 & -71.267 & 125.502 \\
\hline \multirow[t]{2}{*}{9} & 484.765 & & source 5 & 27 & $\operatorname{sink} 3$ & 22.43 & & & & & \\
\hline & & 52.324 & source 5 & 27 & $\operatorname{sink} 4$ & 24.86 & 237.84 & 263.47 & -25.628 & -96.895 & 99.8745 \\
\hline \multirow[t]{2}{*}{10} & 537.089 & & source 5 & 27 & $\operatorname{sink} 4$ & 24.86 & & & & & \\
\hline & & 88.72 & source 6 & 30 & $\operatorname{sink} 4$ & 24.86 & 354.88 & 446.73 & -91.847 & -188.74 & 8.02767 \\
\hline \multirow[t]{2}{*}{11} & 625.809 & & source 6 & 30 & sink 4 & 24.86 & & & & & \\
\hline & & 2.0871 & Memb. bottom & 89.11 & sink 4 & 24.86 & 2.4814 & 10.509 & -8.0277 & -196.77 & $-9 \mathrm{E}-14$ \\
\hline \multirow[t]{2}{*}{12} & 627.896 & & Memb. bottom & 89.11 & sink 4 & 24.86 & & & & & \\
\hline & & 25.627 & Memb. bottom & 89.11 & & & 30.469 & & 30.4686 & -166.3 & 30.4686 \\
\hline 13 & 653.523 & & Memb. bottom & 89.11 & & & & & & & \\
\hline
\end{tabular}

Table 18:-Mass load cascade analysis for case study 4 with regeneration by using PSA

\begin{tabular}{|c|c|c|c|c|c|c|c|c|c|c|c|}
\hline $\begin{array}{c}\text { Interval } \\
\mathrm{k}\end{array}$ & $\begin{array}{c}\text { Cumulative } \\
\text { load } \\
\left(\mathrm{M}_{\mathrm{k}}\right) \\
(\mathrm{mol} / \mathrm{s})\end{array}$ & $\begin{array}{c}\text { Net } \\
\text { interval } \\
\text { Load } \\
\Delta \mathrm{M}_{\mathrm{k}} \\
(\mathrm{mol} / \mathrm{s})\end{array}$ & $\begin{array}{c}\text { Process } \\
\text { sources } \\
\mathrm{SR}_{\mathrm{k}}\end{array}$ & $\begin{array}{l}\text { Sourc } \\
\text { e } \\
\text { conc. } \\
\text { C }_{\mathrm{SR}, \mathrm{k}}\end{array}$ & $\begin{array}{c}\text { Process } \\
\text { Sinks } \\
\text { SK }_{k}\end{array}$ & $\begin{array}{l}\text { Sink } \\
\text { conc. } \\
\text { C }_{\text {SK, },}\end{array}$ & $\begin{array}{c}\text { Interval } \\
\text { Source } \\
\text { flowrate } \\
\Delta \mathrm{M}_{\mathrm{SR}, \mathrm{k}} \\
(\mathrm{mol} / \mathrm{s})\end{array}$ & 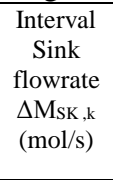 & $\begin{array}{c}\text { Net } \\
\text { flowrate } \\
\Delta \mathrm{S}_{\mathrm{k}} \\
(\mathrm{mol} / \mathrm{s})\end{array}$ & $\begin{array}{c}\text { Cascade } \\
\text { net } \\
\text { flowrate } \\
\text { Cum } \Delta \mathrm{S}_{\mathrm{k}} \\
0 \\
0\end{array}$ & $\begin{array}{c}\text { Cascade } \\
\text { net } \\
\text { flowrate } \\
\text { Cum } \Delta Q_{k} \\
\\
200.005\end{array}$ \\
\hline \multirow[t]{2}{*}{1} & 0 & & & & & & & & & & \\
\hline & & -3.16785 & PSA top & 0.1 & sink 1 & 19.39 & 64.65 & -22.0142 & 86.6643 & 86.66425 & 286.6698 \\
\hline \multirow[t]{2}{*}{2} & -3.16785 & & PSA top & 0.1 & sink 1 & 19.39 & & & & & \\
\hline & & 12.476 & source 1 & 7 & sink 1 & 19.39 & 623.8 & $\begin{array}{l}86.6991 \\
\end{array}$ & $\begin{array}{l}537.1009 \\
\end{array}$ & 623.7651 & 823.7707 \\
\hline \multirow[t]{2}{*}{3} & 9.30815 & & source 1 & 7 & sink 1 & 19.39 & & & & & \\
\hline & & 62.37 & source 2 & 20 & sink 1 & 19.39 & 415.8 & 433.426 & -17.626 & 606.1392 & 806.1447 \\
\hline \multirow[t]{2}{*}{4} & 71.67815 & & source 2 & 20 & sink 1 & 19.39 & & & & & \\
\hline & & 287.3524 & source 3 & 25 & sink 1 & 19.39 & 1436.76 & 1996.889 & -560.127 & 46.01175 & 246.0173 \\
\hline \multirow[t]{2}{*}{5} & 359.0305 & & source 3 & 25 & sink 1 & 19.39 & & & & & \\
\hline & & 29.1023 & source 3 & 25 & sink 2 & 21.15 & 145.511 & 180.2 & -34.6885 & 11.32325 & 211.3288 \\
\hline \multirow[t]{2}{*}{6} & 388.1328 & & source 3 & 25 & sink 2 & 21.15 & & & & & \\
\hline & & 43.92535 & source 3 & 25 & sink 3 & 22.43 & 219.626 & 252.01 & -32.3833 & -21.06 & 178.9455 \\
\hline \multirow[t]{2}{*}{7} & 432.0582 & & source 3 & 25 & sink 3 & 22.43 & & & & & \\
\hline & & 27.72 & source 4 & 25 & sink 3 & 22.43 & 138.6 & 159.0361 & -20.4361 & -41.4962 & 158.5094 \\
\hline \multirow[t]{2}{*}{8} & 459.7782 & & source 4 & 25 & sink 3 & 22.43 & & & & & \\
\hline & & 24.98657 & source 5 & 27 & sink 3 & 22.43 & 113.575 & $\begin{array}{l}143.3538 \\
\end{array}$ & $\begin{array}{l}-29.7785 \\
\end{array}$ & $\begin{array}{l}-71.2747 \\
\end{array}$ & 128.7309 \\
\hline \multirow[t]{2}{*}{9} & 484.7647 & & source 5 & 27 & sink 3 & 22.43 & & & & & \\
\hline & & 51.24343 & source 5 & 27 & sink 4 & 24.86 & 232.924 & 258.0233 & -25.0986 & $\begin{array}{l}-96.3733 \\
\end{array}$ & 103.6322 \\
\hline \multirow[t]{2}{*}{10} & 536.0082 & & source 5 & 27 & sink 4 & 24.86 & & & & & \\
\hline & & 88.71974 & source 6 & 30 & sink 4 & 24.86 & 354.878 & 446.7258 & -91.8468 & -188.22 & 11.78542 \\
\hline \multirow[t]{2}{*}{11} & 624.7279 & & source 6 & 30 & sink 4 & 24.86 & & & & & \\
\hline & & 3.16785 & PSA bottom & 81.05 & $\operatorname{sink} 4$ & 24.86 & 4.16548 & 15.95091 & -11.7854 & -200.006 & $5.51 \mathrm{E}-14$ \\
\hline \multirow[t]{2}{*}{12} & 627.8957 & 0 & PSA bottom & 81.05 & sink 4 & 24.86 & & & & & \\
\hline & & 25.63228 & PSA bottom & 81.05 & & & 33.7045 & & 33.70452 & -166.301 & 33.70452 \\
\hline
\end{tabular}


In case of there is excess load for $\operatorname{sink} j$, it is assumed that, the sink takes its demand from the sources located at its cumulative load intervals with the highest impurity concentration and followed by the water source of the second highest impurity concentration, and so on [32]. As shown in Figure 4, sink 1 takes 1431.4 mol/s from source 3, $415.8 \mathrm{~mol} / \mathrm{s}$ from source 2 and completes its demand from source 1 and the fresh hydrogen. Note that, if sink 1 took $623.8 \mathrm{~mol} / \mathrm{s}$ from source 1 and the remainder $24 \mathrm{~mol} / \mathrm{s}$ from fresh hydrogen, the impurity balance as presented in Equation 2 will not be achieved. Thus, we conclude that there is an excess impurity load from sources located at the sink cumulative load intervals. In this network design it is assumed that there is an excess load from source 1 (lowest impurity concentration). To determine the actual amount of source 1 and the amount of fresh hydrogen added to sink 1 it is assumed that $\mathrm{x}$ amount of source 1 and $\mathrm{y}$ amount of fresh hydrogen are added to sink 1 . The summation of the two amounts is $647.8 \mathrm{~mol} / \mathrm{s}$ according to the flowrate balance of sink 1 (Equation 1). Using equation 1 and 2 , sink 1 takes $519.025 \mathrm{~mol} / \mathrm{s}$ from source 1 and $128.775 \mathrm{~mol} / \mathrm{s}$ from fresh hydrogen source. Note also that, for sink 1 , the excess load can be assumed to be from source 2 or from source 3 . The excess load can be removed from any source located at the sink cumulative load.

Sink 2 takes $145.51 \mathrm{~mol} / \mathrm{s}$ from source 3 and completes its demand from source 1 residual and from the fresh hydrogen. Using Equations 1 and 2 for sink 2, it is noted that sink 2 completes its demand from fresh hydrogen (34.69 mol/s) and no amount added from source 1 residual.

Sink 3 takes $138.6 \mathrm{~mol} / \mathrm{s}$ from source 4 and $108.66 \mathrm{~mol} / \mathrm{s}$ from source 5 and completes its demand from source 1 residual and the fresh hydrogen. The last amount of fresh hydrogen is $33.305 \mathrm{~mol} / \mathrm{s}$. If sink 3 took this amount and $48.81 \mathrm{~mol} / \mathrm{s}$ from source 1 residual, impurity concentration balance of sink 3 according to equation 2 is not achieved. If sink 3 completes its demand from source 1 residual only, impurity concentration in this case also is failed. We conclude that there is excess load from sources located at sink 3 cumulative load intervals. To achieve the impurity concentration balance, $\mathrm{x}$ amount of source 1 residual and $\mathrm{y}$ amount of source 3 are assumed to be supplied to sink 3 . Using Equations 1 and 2, it is found that, $91.23 \mathrm{~mol} / \mathrm{s}$ from source 1 residual and $215.91 \mathrm{~mol} / \mathrm{s}$ from source 3 are supplied to sink 3.

Sink 4 takes its demand from all sources residual from the above cumulative loads intervals, $237.84 \mathrm{~mol} / \mathrm{s}$ from source $5,354.88 \mathrm{~mol} / \mathrm{s}$ from source $6,2.4814 \mathrm{~mol} / \mathrm{s}$ from the membrane bottom product, $33.305 \mathrm{~mol} / \mathrm{s}$ from fresh hydrogen source and all the flowrate of the top product of the membrane $(69.57 \mathrm{~mol} / \mathrm{s})$.

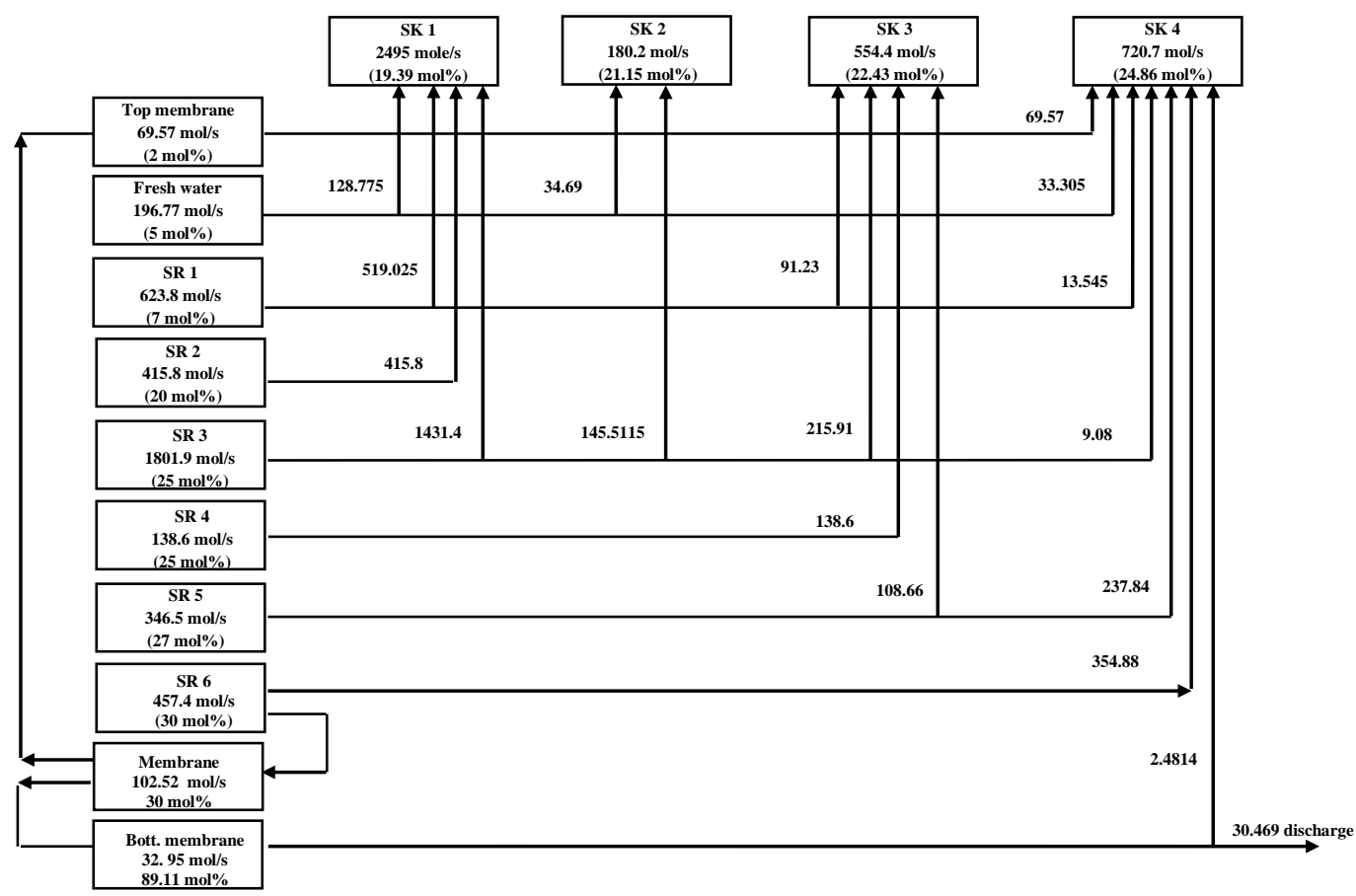

Figure 5:- One of the suggested hydrogen network design for case study 4 with membrane regeneration system 


\section{Conclusion:-}

The work presented in this paper extended the mass problem table to mass load cascade analysis (MLCA) technique. MLCA can be used for water and hydrogen networks with pure and impure fresh utilities. It enables getting the minimum fresh flowrate and discharge flowrate targets and the location of the pinch concentration accurately. In addition, it can be used to regenerate water and hydrogen networks with different types of regeneration systems, i.e single-pass and partitioning regeneration systems. Different case studies of water and hydrogen networks were used to illustrate the MLCA technique. All results obtained are agreed with those presented in the literature.

\section{References:-}

1. B. Linnhoff, D. W. Townsend, D. Boland, G. F. Hewitt, B. E. A. Thomas, A. R. Guy, R. H. A. Marshall, "User Guide on Process Integration for the Efficient Use of Energy," IChemE: Rugby, U.K., 1982.

2. U. V. Shenoy, "Heat Exchanger Network Synthesis: Process Optimization by Energy and Resource Analysis," Gulf Publishing Co.: Houston, TX, 1995.

3. I. C. Kemp, "Pinch analysis and process integration: A user guide on process integration for the efficient use of energy," Elsevier, London, 2007

4. M. M. El-Halwagi and V. Manousiouthakis, "Synthesis of Mass Exchange Networks," AIChE J., Vol. 35, 8, pp. 1233-1244, 1989.

5. El-Halwagi, M. M.; Manousiouthakis, V. Automatic Synthesis of Mass Exchange Networks with Single Component Targets. Chem. Eng. Sci. 1990, 45 (9), 2813-2831.

6. M.M. El-Halwagi, "Pollution Prevention through Process Integration: Systematic Design Tools," Academic Press, San Diego, CA, 1997.

7. M. M. El-Halwagi, "Pollution Prevention through Process Integration," J. Clean Prod. Process, Vol. 1, pp. 5-19, 1998.

8. N. Hallale,D. M. Fraser, "Capital and Total Cost Targets for Mass Exchange Networks," Part 1 and 2, Comput. Chem. Eng., Vol. 23, 1661-1699, 2000.

9. N. Hallale, D. M. Fraser, "Super targeting for Mass Exchange Networks,"Part 1 and 2, Trans. Inst. Chem. Eng., Part A, Vol. 78, pp. 202-216, 2000.

10. Y. P. Wang, and R. Smith, "Wastewater Minimisation," Chem. Eng. Sci., Vol. 49, pp. 981-1006, 1994.

11. G. T. Polley, and H. L. Polley, "Design Better Water Networks,"Chem. Eng. Prog., Vol. 96, no 2, pp. 47-52, 2000.

12. Hallale, N. A New Graphical Targeting Method for Water Minimisation. AdV.EnViron. Res. 2002, 6 (3), 377 390.

13. Z. A. Manan, Y. L. Tan, and D. C. Y. Foo, "Targeting the Minimum Water Flowrate Using Water Cascade Analysis Technique, “AIChE J., Vol. 50, no12, pp. 3169-3183, 2004.

14. Aly, S.; Abeer, S.; Awad, M. A New Systematic Approach for Water Network Design. Clean Technol. EnViron. Policy 2005, 7, 154161.

15. El-Halwagi, M. M.; Gabriel, F.; Harell, D. Rigorous Graphical Targeting for Resource Conservation via Material Recycle/Reuse Networks. Ind. Eng. Chem. Res. 2003, 42, 4319-4328.

16. Almutlaq, A. M.; Kazantzi, V.; El-Halwagi, M. M. An algebraic approach to targeting waste discharge and impure fresh usage via material recycle/reuse networks. Clean Technol. EnViron. Policy 2005, 7, 294-305.

17. Towler, G. P.; Mann, R.; Serriere, A. J-L.; Gabaude, C. M. D. Refinery Hydrogen Management: Cost Analysis of Chemically Integrated Facilities. Ind. Eng. Chem. Res. 1996, 35 (7), 2378-2388.

18. Alves, J. J.; Towler, G. P. Analysis of Refinery Hydrogen Distribution Systems. Ind. Eng. Chem. Res. 2002, 41, 5759-5769.

19. Foo D. C. Y., Manan Z. A., Tan Y. L., Synthesis of Maximum Water Recovery Network for Batch Process Systems. J. Cleaner Production, 2005, 13 (15), 1381-1394.

20. Liu G., Li H., Feng X., Deng C., Chu K. H.,2013, A conceptual method for targeting the maximum purification feed flow rate of hydrogen network. Chemical Engineering Science 88, 33-37.

21. Wang Y., Jin J., Feng X., Chu K. H., Optimal Operation of Refinery's Hydrogen Network. Ind. Eng. Chem. Res. 2014, 53, 14419-14422.

22. Manan, Z. A.; Tan, Y. L.; Foo, D. C. Y. Targeting the Minimum Water Flowrate Using Water Cascade Analysis Technique. AIChE J. 2004, 50 (12), 3169-3183.

23. Prakash, R.; Shenoy, U. V. Targeting and Design of Water Networks for Fixed Flowrate and Fixed Contaminant Load Operations. Chem. Eng. Sci. 2005, 60 (1), 255-268. 
24. Deng, Chun \& Zhou, Yeyang \& Feng, Xiao. (2017). Optimal Design of Refinery Hydrogen Network with Mixed Pattern Configuration. 10.1016/B978-0-444-63965-3.50142-2.

25. Jagannath, Anoop \& Mouli R Madhuranthakam, Chandra \& Elkamel, A \& Karimi, Iftekhar \& Almansoori, Ali. (2018). Retrofit Design of Hydrogen Network in Refineries: Mathematical Model and Global Optimization. Industrial \& Engineering Chemistry Research. doi: 57. 10.1021/acs.iecr.7b04400.

26. W.M. Shehata, A.M. Shoaib, F.K. Gad. Modeling water and hydrogen networks with partitioning regeneration units. Egyptian Journal of Petroleum, Vol. 24,1, 2015, pp. 77-85

27. W.M. Shehata, A.M. Shoaib. Simple optimization method for partitioning purification of hydrogen networks. Egyptian Journal of Petroleum, Volume 24, Issue 1, 2015, pp. 87-95

28. S. Hwangbo, S. Lee, C. Yoo. Optimal network design of hydrogen production by integrated utility and biogas supply networks. Applied Energy, Vol. 208, 2017, Pages 195-209

29. Foo D. C. Y., Manan Z. A., 2006. Setting the minimum utility gas flowrate targets using cascade analysis technique. Ind. Eng. Chem. Res., 2006, 45(17), 5986-5995.

30. D. K. S. Ng, D. C. Y. Foo, and R. R. Tan, "Automated targeting technique for single-impurity resource conservation networks, Part 2: Single-pass and partitioning waste-interception systems, “Ind. Eng. Chem. Res., vol. 48, no. 16, pp.7647-7661, 2009.

31. G. Parthasarathy, and G. Krishnagopalan, "Systematic reallocation of aqueous resources using mass integration in a typical pulp mill,". Advances in Environmental Research, vol. 5, no. 1, pp. 61-79, 2001.

32. D. C. Y. Foo, "Water Cascade Analysis for Single and Multiple Impure Fresh Water Feed, "Trans IChemE, Part A, Chemical Engineering Research and Design, 2007,vol. 85, A8, pp. 1169-1177, 2007.

33. V. Agrawal, and U. V. Shenoy, "Unified conceptual approach to targeting and design of water and hydrogen networks," AIChE J., 2006, vol. 52, no. 3, pp.1071-1082, 2006.

34. N. Hallale, And F. Liu, "Refinery Hydrogen Management for Clean Fuels Production,". Adv..Environ. Res.,Vol. 6, pp. 81-98, 2001. 